\title{
The Aryl Hydrocarbon Receptor in Asthma: Friend or Foe?
}

\author{
Odile Poulain-Godefroy ${ }^{(0)}$, Mélodie Bouté, Julie Carrard, Daniel Alvarez-Simon ${ }^{\circledR}$, \\ Anne Tsicopoulos *(i) and Patricia de Nadai 1
}

University of Lille, CNRS, Inserm, CHU Lille, Institut Pasteur de Lille, U1019-UMR9017-CIIL-Centre d'Infection et d'Immunité de Lille, F59000 Lille, France; odile.poulain@pasteur-lille.fr (O.P.-G.);

melodie.boute@outlook.fr (M.B.); carrard.julie@orange.fr (J.C.); danielalvarezsimon@gmail.com (D.A.-S.); patricia.de-nadai@pasteur-lille.fr (P.d.N.)

* Correspondence: anne.tsicopoulos@pasteur-lille.fr

Received: 9 November 2020; Accepted: 18 November 2020; Published: 20 November 2020

\begin{abstract}
The aryl hydrocarbon receptor $(\mathrm{AhR})$ is a ligand-activated transcription factor that has emerged as an important player in asthma control. AhR is responsive to environmental molecules and endogenous or dietary metabolites and regulates innate and adaptive immune responses. Binding of this receptor by different ligands has led to seemingly opposite responses in different asthma models. In this review, we present two sides of the same coin, with the beneficial and deleterious roles of AhR evaluated using known endogenous or exogenous ligands, deficient mice or antagonists. On one hand, AhR has an anti-inflammatory role since its activation in dendritic cells blocks the generation of pro-inflammatory $\mathrm{T}$ cells or shifts macrophages toward an anti-inflammatory M2 phenotype. On the other hand, AhR activation by particle-associated polycyclic aromatic hydrocarbons from the environment is pro-inflammatory, inducing mucus hypersecretion, airway remodelling, dysregulation of antigen presenting cells and exacerbates asthma features. Data concerning the role of AhR in cells from asthmatic patients are also reviewed, since AhR could represent a potential target for therapeutic immunomodulation.
\end{abstract}

Keywords: asthma; aryl hydrocarbon receptor; immunity

\section{Introduction}

Asthma is an inflammatory disorder of the airways leading to bronchial hyperreactivity and airway obstruction. In this context, the lung barrier surface is crucial to maintain the integrity of the host following exposure to different events. Lung epithelial cells express receptors that detect environmental stimuli, secrete danger signals, and orchestrate defence against inhaled microorganisms, allergens and pollutants. In asthma, the epithelial barrier integrity is compromised, as the epithelium fails to appropriately repair. Furthermore, there is an epithelial immune deviation in mediator production, resulting in inappropriate recruitment and skewing of downstream adaptive immune responses [1]. The mechanisms linking environment and immunity are still not completely understood but may involve environmental sensors. The aryl hydrocarbon receptor (AhR) is a conserved ligand-activated transcription factor highly expressed in the lungs from both humans and mice [2,3]. AhR is a sensor of environmental pollutants, diet molecules, microbial components and metabolic signals that controls complex transcriptional programmes which are ligand- and cell-type- specific. In the last few years, a large body of evidence has shown that AhR is involved in maintaining homeostasis or in eliciting pathology by modulating the biological responses of critical cell types at the barrier and mucosal interfaces. In this review, we summarize our current knowledge about AhR and the cell programmes it controls related to asthma pathophysiology. 


\subsection{Mechanisms of AhR Activation}

Upon ligand binding, AhR functions as a transcription factor that affects gene expression via translocation to the nucleus, promoter binding, recruitment of co-activators and co-repressors at specific DNA regions (harbouring or not AhR-responsive DNA elements also known as xenobiotic response elements (XRE)), and via interactions with signal transduction machinery in mouse and human cells. Detailed AhR signalling pathways have been extensively reviewed recently [4-6] and are summarized in Figure 1.

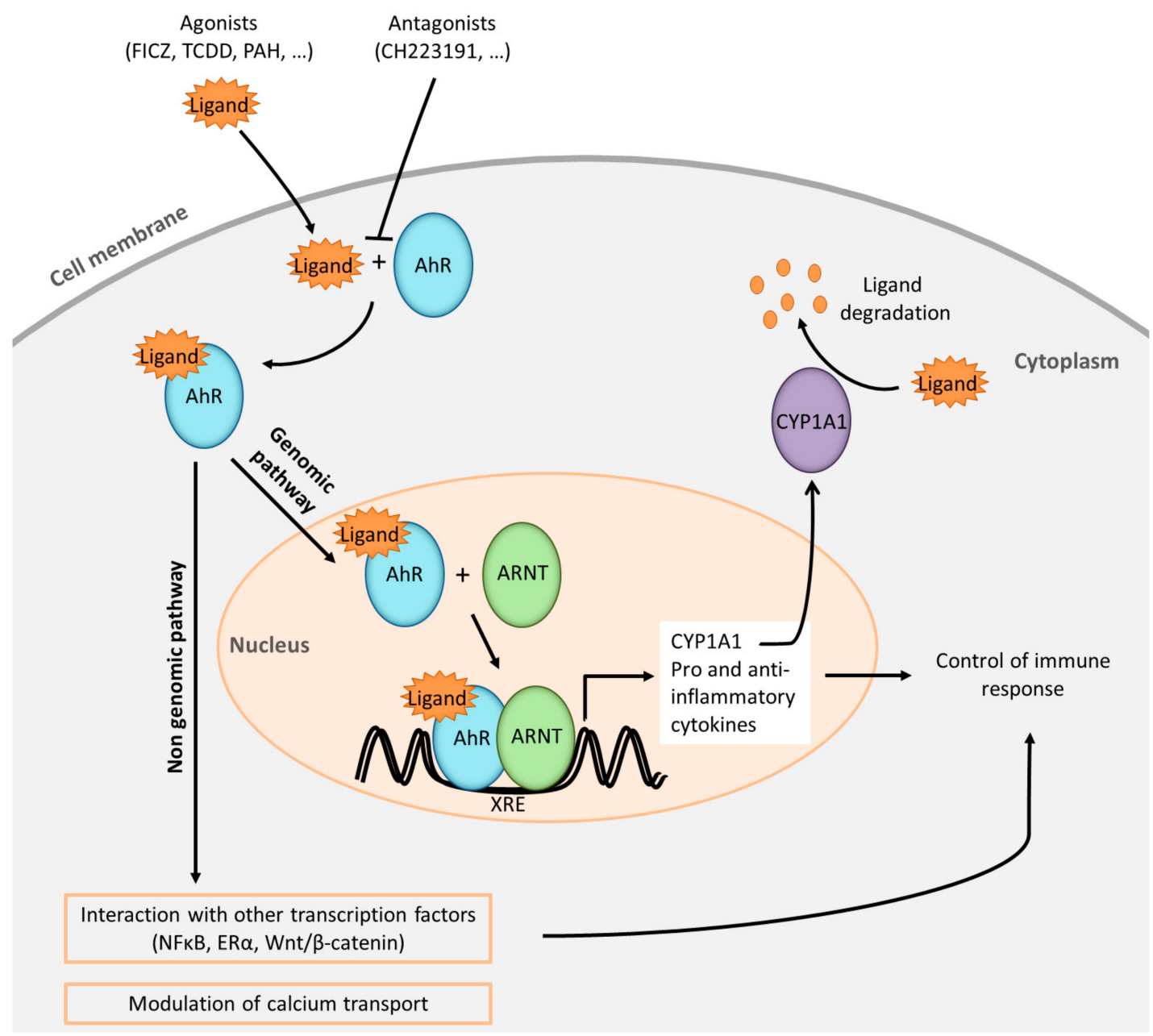

Figure 1. Simplified representation of aryl hydrocarbon receptor (AhR) pathways. AhR ligands (FICZ: 6-formylindolo [3,2-b]carbazole; TCDD: 2, 3, 7, 8-tetrachlorodibenzo-p-dioxin; PAH: polycyclic aromatic hydrocarbons) cross the plasmatic membrane and bind to AhR present in the cytoplasm. The presence of antagonists in the medium is susceptible to block the interaction with the agonists. The ligand-receptor complex translocates into the nucleus and the complex heterodimerizes with its partner ARNT (AhR Nuclear Translocator). The heterodimer binds specific DNA sequences located in the promoter regions of target genes known as xenobiotic response elements (XRE). Among target genes, CYP1A1 (Cytochrome P450, family 1, subfamily A, polypeptide 1) is a hallmark of AhR signalling. CYP1A1 protein is a member of the cytochrome P450 superfamily of enzymes which one of their roles is to degrade the AhR natural ligands. Numerous genes coding for pro-inflammatory and anti-inflammatory products are induced by this mechanism, which is referred to as the AhR genomic pathway. Non-genomic pathways are also described such as interactions of AhR with other transcription factors or modulation of calcium transport. Altogether these AhR pathways are able to control positively or negatively the immune response. 


\subsection{AhR Ligands}

Different exogenous AhR ligands have been identified including not only classic xenobiotic AhR agonists (such as 2,3,7,8-tetrachlorodibenzo-p-dioxin (TCDD) and polycyclic aromatic hydrocarbons (PAHs)) [7], but also bacterial pigments from Pseudomonas aeruginosa and Mycobacterium tuberculosis [8], and even allergens ([9] and unpublished data). Endogenous ligands include tryptophan metabolites like the 6-formylindolo[3,2-b]carbazole (FICZ), the kynurenines, ligands provided by commensal microbiota [10], dietary components derived from vegetables [11] and other metabolites such as bilirubin and arachidonic acid derivatives [12,13]. The AhR ligands discussed in this review are listed in Table 1. Recent data have shown that AhR is critical for a wide range of immune functions including the maintenance of innate and adaptive cell populations at mucosal barrier sites, and the control of inflammation at steady-state or during ongoing inflammatory responses, such as asthma.

Table 1. List of discussed AhR ligands.

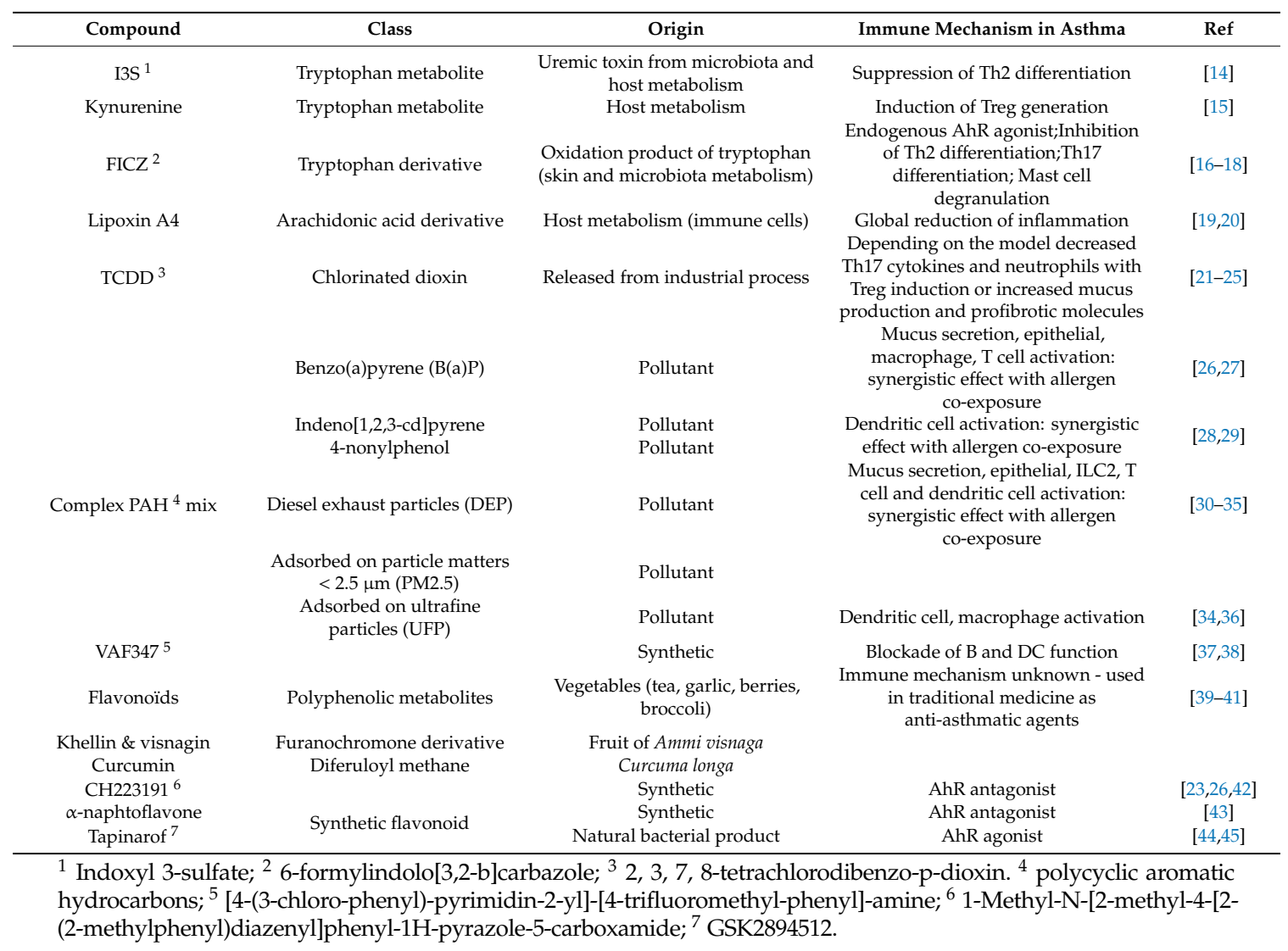

\section{AhR Is Expressed in Many Immune Cells Involved in Asthma Pathophysiology}

Asthma is characterized by a bronchial inflammatory reaction and an abnormal bronchospastic response to allergens and irritants, in which several cellular components of the innate and adaptive immune system act together with epithelial cells to cause bronchial hyperreactivity. Many immune cell types involved in the asthmatic response express AhR (Figure 2), and their co-activation by AhR ligands can regulate the outcome of the reaction. 


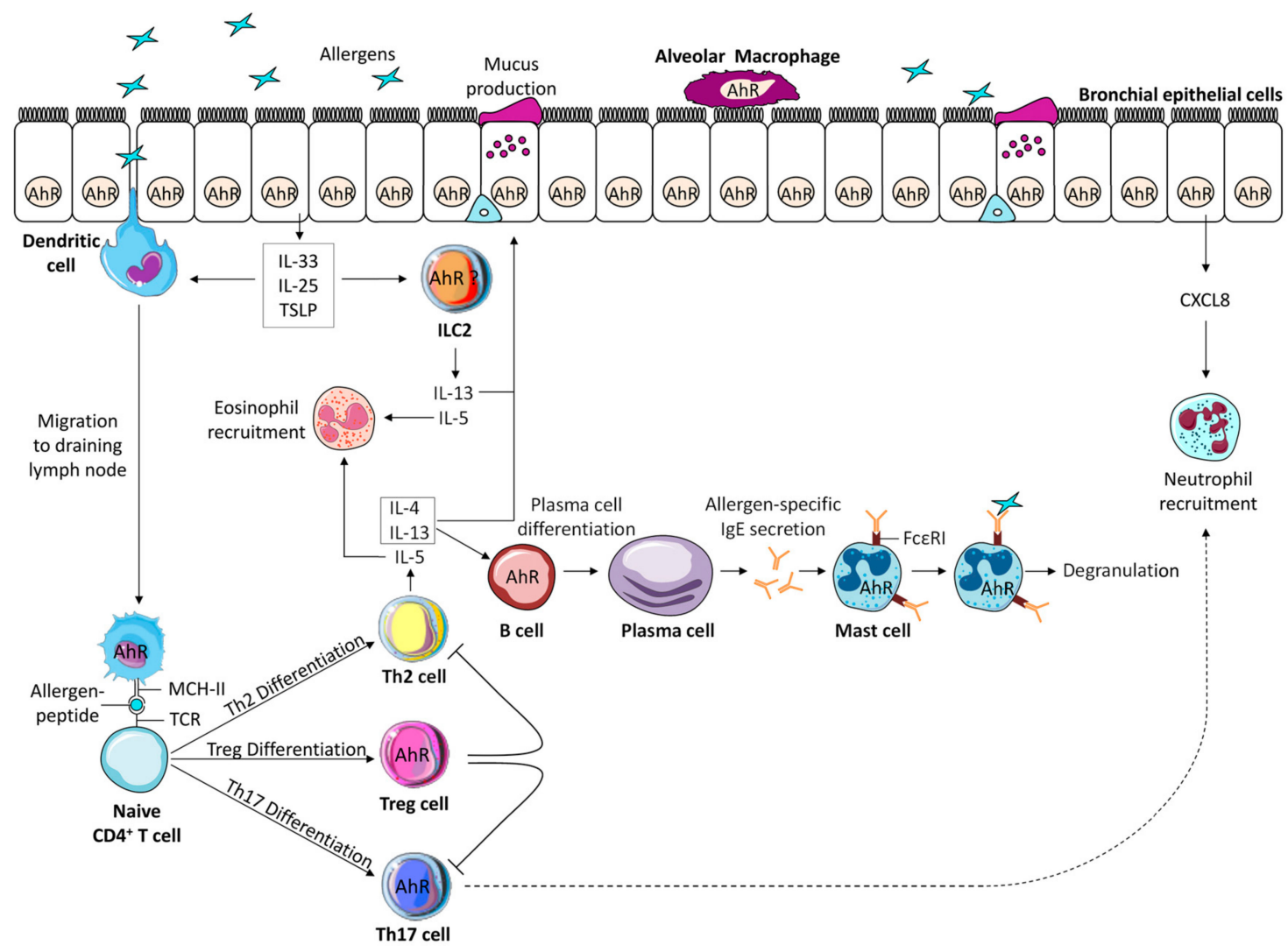

Figure 2. Aryl hydrocarbon receptor (AhR) expression in the different cells involved in the pathophysiology of asthma. The asymptomatic sensitization phase involves allergen presentation by antigen presenting cells to naive T cells leading to Th2 differentiation, production of interleukin (IL)-4 and IL-13 that activates B cells to differentiate into plasma cells producing allergen-specific IgE that bind to high affinity IgE receptors expressed by mast cells. Among these cells, macrophages, dendritic cells, and B cells express AhR. The effector phase of the asthmatic reaction following a second allergen contact, involves IgE dependent immediate release of mast cell mediators leading to bronchial smooth muscle cell contraction, activation of epithelial cells that release the pro-type 2 cytokines IL-33, Thymic Stromal Lymphopoietin (TSLP), IL-25, activation of innate lymphoid cells type 2 (ILC2) and Th2 cells and eosinophil recruitment. In some forms of asthma, Th17 cells are also activated leading to the recruitment of neutrophils, which are also attracted by the release of CXCL8 by epithelial cells. Epithelial cells, mast cells, Th17 cells and potentially ILC2 express AhR. Finally, an important negative regulator of the allergic reaction is represented by Treg that also express AhR. The co-activation of all these cells by AhR ligands can modify the outcome of the asthmatic reaction (see text for details).

Among asthma phenotypes, the most common is the type 2 phenotype triggered by allergen stimulation $[46,47]$. The pathophysiology of the asthmatic reaction starts with an asymptomatic sensitization phase involving lung antigen-presenting cells, that while being exposed to environmental and endogenous AhR ligands, uptake and process the allergen. Then, allergen presentation by dendritic cells (DC) to naive T cells leads to the production of Th2 cytokines and to the activation of B cells that differentiate into allergen-specific IgE-producing plasma cells. These IgE antibodies bind to the high IgE affinity receptors expressed on mast cells and basophils awaiting a later allergen exposure. Both DC and macrophages express $\mathrm{AhR}$, and recent data show that AhR acts upstream of DC by directing human monocyte fate towards DC rather than macrophages [48] suggesting that AhR stimulation may favour DC-dependent mechanisms.

A second allergen contact triggers the effector phase of the reaction. Crosslinking of the allergen to IgE bound to the high affinity IgE receptors expressed by mast cells and basophils induce the release of mediators (including preformed histamine, and synthesized prostaglandins and leukotrienes) leading 
to smooth muscle bronchoconstriction. In this context, it is of interest that human and murine mast cells constitutively express $\mathrm{AhR}$, and that antigen-specific IgE crosslinking in the presence of a single dose of the AhR ligand FICZ boost mast cell degranulation whereas repeated exposure leads to inhibition of degranulation [16]. It was recently shown that part of FICZ effect was mediated by ORMLD3 (an asthma candidate gene) that induces sphingosine-1-phosphate metabolite and activates mast cell degranulation [49-51]. Altogether, these data suggest that AhR in mast cells may play a role in the immediate allergic reaction.

Allergen exposure also activates lung epithelial cells and their release of numerous pro Th2 cytokines such as interleukin (IL)-33, IL-25 and Thymic Stromal Lymphopoietin (TSLP), and chemokines such as C-C motif ligand (CCL)11 (eotaxin-1) and CCL17 (TARC). Epithelial cells constitutively express $\mathrm{AhR}$, and as a cell at the interface with the environment, is central to the regulation of the asthmatic reaction. In human bronchial epithelial cells, while constitutively active unligated AhR suppresses the production of the chemokines CXCL8 and CCL5, AhR ligands alone induce the production of CXCL8 [52], underscoring the duality of AhR in inflammation, starting at the level of epithelial cells.

The release of the aforementioned mediators drives the development of the allergic inflammatory reaction, characterized by pulmonary recruitment of Th2 cells, eosinophils, airway hyperresponsiveness and mucus hyper-secretion [53,54]. Besides the classical adaptive Thelper (Th) responses, a novel actor of the asthmatic reaction belonging to the family of Innate lymphoid cells (ILC) [55], has been more recently uncovered. ILC are preferentially distributed at mucosal sites, do not express antigen receptors, but respond to cytokines in their environment. The cytokine pattern that they produce mirrors the classical T helper cell populations, with type 1 ILC1,type 2 ILC2 and type 3 ILC3 being the innate counterparts of respectively Th1, Th2 and Th17/Th22 cells. ILC2 produce IL-13 and IL-5 upon stimulation by IL-33, IL-25 or TSLP and contribute to clinical and experimental asthma, through induction of lung eosinophilia, mucus hyper-production and airway hyperresponsiveness [55]. Hitherto, lung ILC3 have been found only in some forms of experimental asthma, in particular associated with obesity [56,57]. Ahr is highly expressed in gut ILC2 and ILC 3 , and gain of function of $A h r$ results in ILC2 suppression but promotes ILC3 function [58-61], suggesting that Ahr favours Th17-type cytokine production by subtle counter regulation in ILC subsets at least at the gut level. Although several studies have shown that AhR ligands containing pollutants induce Th17-type responses, no study has yet explored their effects on lung ILC3.

Some forms of asthma exhibit a Th17 high profile that may contribute to their severity, whereas the induction of Treg is considered as beneficial. AhR expression varies in different $\mathrm{T}$ cell subsets, with levels being the highest in Th17 and Treg cells, and the lowest in Th1 and Th2 cells [62]. It was only in the $2000 \mathrm{~s}$ that AhR took a central place in the regulation of T cell biology. It was shown that AhR is upregulated in developing Th17 cells, and boosts the production of Il-17 and Il-22 [63-65] in mice and of IL-22 in humans [66,67]. Accordingly, Ahr deficient mice exhibit decreased Il-22 production by Th17 cells [65]. However, Ahr ligands may differentially impact Th17-mediated disease outcomes with FICZ favouring and TCDD inhibiting this profile $[64,65]$. Ahr expression is induced by signal transducer and activation of transcription 3 during Th17 differentiation [68], and it suppresses Stat5 and Stat1 signalling that interferes with Th17 generation allowing a positive feedback loop [63]. Collectively, Ahr appears to play a role in the early stages of Th17 differentiation, whereas the development of fully pathogenic effector Th17 cells requires other factors [69].

However, Forkhead box P3 (FOXP3) ${ }^{+} \mathrm{T}$ regulatory cells (Treg) and IL-10 producing type $1 \mathrm{~T}$ regulatory cells $(\operatorname{Tr} 1)$ cells have also been linked to AhR activation [70,71]. In contrast to FICZ that promotes Th17 differentiation, AhR ligands such as TCDD or kynurenine increase Foxp3 expression through different mechanisms including epigenetic modifications of $\mathrm{T}$ cells and modulation of DC [15,72]. These epigenetic modifications of T cells, in particular DNA methylation, allows differentiation of different sub-populations and contributes to flexibility and plasticity among CD4+ T cell subsets [73]. In asthma patients, increased methylation of FOXP3 in peripheral blood Treg cells has been associated with their functional impairment in an environment of high ambient 
air pollution levels compared to asthmatic individuals with low air pollution levels [74]. For $\operatorname{Tr} 1$ cells, it has been demonstrated that their Ahr expression is boosted by Il-27, a pleiotropic cytokine with diverse immune regulatory activities, through a mechanism driven by Stat3 [75]. This activation influences the transcriptional program of $\operatorname{Tr} 1$ cells leading to the production of the immunosuppressive cytokine Il-10. It is noteworthy that activin- $A$, a member of the transforming growth factor- $\beta$ (TGF- $\beta$ ) superfamily, has been described to induce the transcription factors IRF4 and AhR in human CD4 ${ }^{+}$ $\mathrm{T}$ cells, leading to the generation of Tr1-like cells able to suppress allergic responses in a model of humanized mice [76]. Interestingly, in established Th17 cells, Ahr can convert them into Il-10-producing Tr1 cells [77], a process that has been observed in allergic rhinitis [78]. Therefore, Ahr may be linked to plastic Th17 cells that require additional information to complete their differentiation into either fully pathogenic Th17 cells or regulatory Tr1 cells.

In addition, the development of a humoral response in asthma is fundamental for the sensitization process and development of the immediate bronchospastic reaction through IgE synthesis. AhR is expressed in B cells, and a previous study has shown that the AhR agonist [4-(3-chloro-phenyl)-pyrimidin-2-yl]-[4-trifluoromethyl-phenyl]-amine (VAF347) inhibits IgE synthesis by human B cells [37]. More recently, the role of Ahr in B cells has been revisited and shown to regulate $B$ cell fate decisions by favouring memory $B$ cells but repressing terminally differentiated antibody-secreting plasma cells in vivo [79]. Moreover, Ahr can promote Il-10-producing B regulatory cells (Breg) [80], in part through its activation by microbiota-derived butyrate [81]. Therefore, AhR is also involved in $\mathrm{B}$ cell regulation and may serve as a molecular rheostat to brake the effector response, possibly to facilitate optimal recall responses.

In summary, AhR regulates the innate and adaptive response at multiple levels with lineage-specific effects likely to differentially regulate the outcomes of the asthmatic reaction. These outcomes are reviewed in the following sections, and show both beneficial and deleterious effects in the asthma response either by the use of gene silencing, knock out mice or AhR antagonists.

\section{AhR and Its Beneficial Effects in Experimental Asthma}

\subsection{AhR Activation is Modulated by epigenetic Mechanisms in Bronchial Epithelial Cells, And Prevents Airway Inflammation}

Epigenetic variations have been associated with asthma and its severity in various cells and have evidenced an important role for DNA methylation in asthma pathogenesis [82,83]. For example, ten-eleven translocation 1 (TET1) promoter methylation has been associated with childhood asthma [84]. In vivo, house dust mite (HDM)-challenged Tet1 ${ }^{-/}$mice exhibit increased allergic airway inflammation. Lung transcriptomic analysis of these mice has revealed a downregulation of genes involved in Ahr signalling, including Cyp1a1 and Aldh1a1, and an increase in interferon signalling compared to Tet $1^{+/+}$ mice. In human bronchial epithelial cells, activation of TET1 also differentially regulates interferon and AhR signalling pathways. Genes in these pathways are associated with changes in DNA methylation, predicted binding of transcriptional factors with relevant functions in their promoters, and the presence of histone marks generated by histone enzymes that are known to interact with TET1. Collectively, these data suggest that TET1 prevents allergic airway inflammation through inhibition of the interferon and activation of the AhR signalling pathways in airway epithelial cells, probably through epigenetic modifications [85].

\subsection{AhR Activation in Dendritic Cells Blocks the Generation of Pro-Inflammatory T Cells}

Antagonizing AhR in human progenitor cells induces their differentiation in DC able to activate pro-inflammatory cells [86] suggesting an anti-inflammatory role of AhR in DC. Accordingly, Ahr-- mice sensitized and challenged with ovalbumin (OVA) develop an increased inflammatory response in the lung compared with wild type (WT) controls, with greater numbers of inflammatory eosinophils and neutrophils, increased T-cell proliferation, production of Th2 cytokines, and higher levels 
of OVA-specific IgE and IgG1. Mechanistically, murine Ahr-deficient lung DC induce increased allergen-specific T cell priming, proliferation and levels of Th2 and Th17 cytokines, and are more highly activated than WT DC [17]. Furthermore, when murine pulmonary DC are incubated overnight with lipopolysaccharide (LPS) and OVA, the addition of 100 or $200 \mathrm{nM} \mathrm{FICZ} \mathrm{inhibits} \mathrm{the} \mathrm{proliferation}$ of $\mathrm{T}$ cells demonstrating that $\mathrm{Ahr}$ is an important negative regulator of allergen-dependent $\mathrm{T}$ cell activation in vitro [17]. These data have been confirmed in an in vivo murine model of allergic asthma, where intraperitoneal injection of FICZ during sensitization to OVA reduces pulmonary eosinophilia and expression of Th2 cytokines. The mechanism involved is the inhibition by FICZ of Stat6, a transcription factor necessary for Th2 differentiation [18]. Other agonists of AhR have been reported to have similar effects. VAF347 is a low molecular weight compound, targeting only DC and B cells, initially screened for its capacity to inhibit IgE production in B lymphocytes. In vitro, VAF347 reduces the expression of IL-6, and of the stimulatory molecules CD86, and HLA-DR by DC, thereby blocking the generation of functional human Th cells. VAF347 is able to inhibit OVA-induced pulmonary allergic inflammation in vivo by blocking lung eosinophilia, serum IgE, and goblet cell hyperplasia [37]. These data and the fact that VAF347 similarly inhibits allergic lung inflammation in B cell-deficient mice suggest that its in vivo biological effects are mainly mediated through DC. Later on, AhR was identified as the pathway mediating the effects of VAF347. Accordingly, in a mouse model of allergic lung inflammation, VAF347-induced reduction in total IgE and Il-5 serum levels was abolished in $A h r^{-/-}$mice [38]. Therefore, the interaction of this compound with the AhR protein in DC is essential for the induction of a potent anti-inflammatory phenotype.

In summary, in these studies, early activation of AhR expressing DC either with FICZ or with VAF347 in the context of an allergic reaction is able to inhibit their ability to activate pro-inflammatory T cells.

\subsection{AhR in Mesenchymal Stem Cells Shifts Macrophages towards An Anti-Inflammatory M2 Phenotype}

Another beneficial effect of AhR has been shown at the level of mesenchymal stem cells (MSC). These cells are multipotent progenitor cells that express Ahr, suppress lung inflammation [87] and participate in tissue repair and remodelling by differentiating into a number of mature cell types. MSC control inflammation by balancing the polarization to pro-inflammatory M1 and alternatively activated anti-inflammatory M2 macrophages [88]. MSC have been involved in cockroach allergy. Cockroach allergen disturbs airway epithelial integrity through protease-activated receptor-2, which leads to increased penetration of allergens, directly activating epithelial cells and their production of cytokines and chemokines [89]. In a mouse model of cockroach allergen-induced allergic airway inflammation, an increased recruitment of MSC was observed in the airways, a process probably mediated through Tgf- $\beta 1$ release, whereas in vitro, MSC inhibited cockroach allergen-induced $\mathrm{CD} 4^{+} \mathrm{T}$ cell cytokine secretion [90], suggesting a protective role of MSC in this model. In another study in the same model, Ahr was demonstrated to be activated by cockroach allergen in bone marrow-derived MSC [9] and to be necessary for MSC airway migration [9]. There was a protective role of Ahr in this model. Indeed, the deletion of Ahr, exacerbated cockroach allergen-induced lung inflammation with peribronchial inflammation, goblet cell hyperplasia and decreased $\mathrm{CD} 4{ }^{+} \mathrm{CD} 25^{+} \mathrm{Foxp} 3^{+}$Treg and MSC recruitment [9].

Several AhR-dependent mechanisms have been involved in the suppressive effects of MSC. Ahr activation by TCDD in MSC upregulates the expression of inducible nitric oxide synthase (iNOS), which promotes the production of nitric oxide (NO), thus enhancing the inhibitory effect of MSC on lymphocyte proliferation [91]. Moreover, in the cockroach-induced asthma model, the AhR inhibitor CH223191 [42] antagonizes MSC-induced macrophage switch from a pro-inflammatory M1 towards an anti-inflammatory M2 phenotype [92], indicating a beneficial role for Ahr through M2 macrophages. In summary, the recruited MSC, activated through Ahr by environmental pollutants or cockroach allergen or both synergistically, release anti-inflammatory factors (e.g., iNOS and Tgf- $\beta 1$ ) and modulate macrophage polarization that suppresses airway inflammation. 


\subsection{AhR Activation Suppresses Th2 Differentiation and Controls T Cell Activation}

AhR plays an important role in T cell regulation. Among AhR exogenous ligands, TCDD is the most potent congener of chlorinated dioxins, a large class of environmental pollutants produced as a byproduct of various industrial processes. Many of the toxic effects resulting from TCDD exposure, including immunosuppression, are mediated by AhR. As stated in the previous section, TCDD has been mainly involved in the generation of Treg. In a non-eosinophilic model of OVA/LPS- sensitized mice, oral administration of TCDD decreased neutrophil recruitment, Th17 cytokine expression and airway hyperresponsiveness, but increased Il-10 production and CD4+CD25+ Tregs. In this model, DC maturation was not impaired [21] suggesting a direct effect of TCDD on T cells.

Besides TCDD, other AhR ligands can have inhibitory effects. The endogenous metabolite uremic toxin indoxyl 3-sulfate (I3S) is able to inhibit the differentiation of Th2 cells but not Th1 cells [14]. In a murine model of OVA-induced allergic asthma, intraperitoneal injections of I3S suppressed pulmonary eosinophilia, serum IgE level and lung Th2 cytokines. In this model, I3S decreased the frequency of Il-4-producing T cells in mediastinal lymph nodes and inhibited activation of Stat 5 and Stat6 associated with Il-4-mediated Th2 differentiation. Accordingly, the AhR antagonist $\alpha$-naphtoflavone suppressed the effects of I3S on Th2 differentiation [43], indicating that I3S regulates Th2 differentiation in an Ahr-dependent manner [14]. Therefore, I3S might be a potential therapeutic target in type 2 asthma.

The beneficial role of AhR on T cell activity modulation was also demonstrated in another study evaluating ozone, an air pollutant that causes respiratory inflammation and exacerbates asthma. Upon chronic ozone exposure in mice, Ahr is activated in the lung, and lipoxin A4, an anti-inflammatory molecule and AhR ligand [19] is released in broncho-alveolar lavage fluids [20]. In this model, $A h r$-deficient mice exhibited an increase in cell recruitment, airway hyperreactivity, epithelial cell injury, inflammation, and fibrosis suggesting that Ahr regulates lung inflammation and epithelial damage after ozone exposure [20]. The expression of $A h r$ in T cells was necessary to control ozone-induced lung inflammatory cell infiltration, as shown in mice with a T cell-specific Ahr deletion. After 6 weeks of ozone exposure, IL-17 and IL-22 production were higher in the lung when the Ahr gene was missing, suggesting an impact of Ahr on the recruitment of lung Il-22-producing cells. For Il-17, Ahr acted directly on cell production and indirectly on cell recruitment. Lastly, Il-17- and Il-22- neutralizing antibodies attenuated lung inflammation in $\mathrm{Ahr}^{-/-}$and control mice [20]. Therefore, ozone exposure activates Ahr, which plays a beneficial role in controlling ozone-induced lung inflammation and airway hyperresponsiveness via the reduction of Th17 cytokine expression. The beneficial effects of AhR activation in asthma are summarized in Figure 3.

AhR ligand direct beneficial effects on T cells are shown in Table 2. Altogether, these data suggest that AhR can inhibit the asthmatic allergic reaction through either increased Treg or decreased Th2 cell activation according to the AhR ligand used. Of note, several natural compounds such as curcumin [39], flavonoids from dietary source [40] or compounds present in traditional medicine [41] have been shown to be AhR ligands and are currently proposed as anti-asthmatic agents. Nevertheless, the demonstration of their direct effect on asthma through Ahr signalling in animal models is still lacking. 


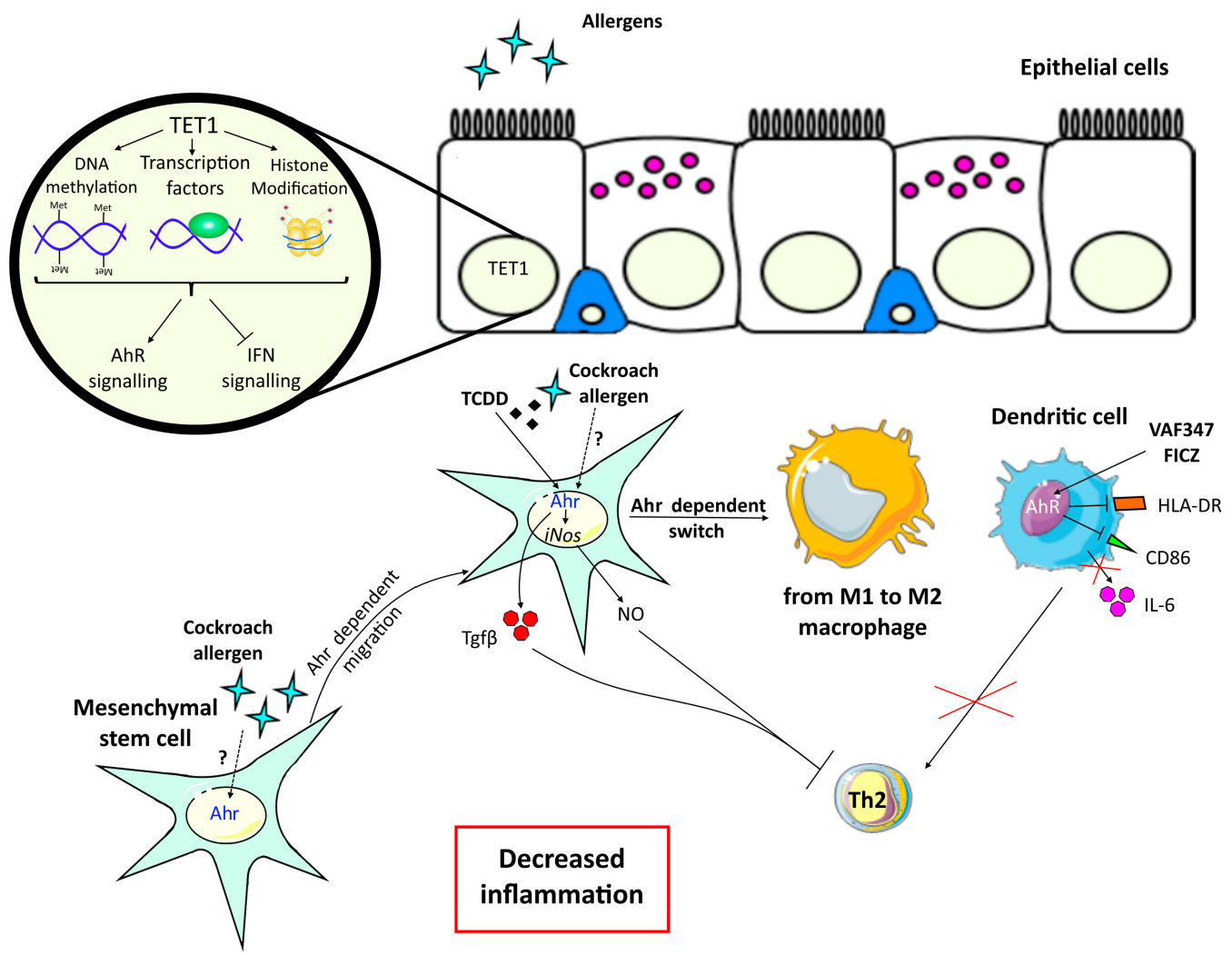

Figure 3. Beneficial effects of aryl hydrocarbon receptor (AhR) activation in asthma. Ten-Eleven Translocation 1 Gene Protein (TET1) is a demethylase that induces epigenetic modification and acts on DNA methylation, transcription factors binding or histone modifications. In epithelial cells, TET1 activation blocks interferon (IFN) signalling and induces AhR signaling, promoting an anti-inflammatory phenotype in asthma models. Mesenchymal stem cells (MSC) express Ahr that can be activated by cockroach allergen leading to their recruitment and migration to the airways. These cells then induce a switch from M1 to M2 anti-inflammatory macrophages. Ahr activation of MSC either by 2,3,7,8-tetrachlorodibenzo-p-dioxin (TCDD) or cockroach allergen upregulates the expression of inducible nitric oxide synthase (iNOS) and secretion of nitric oxide (NO) and Tgf- $\beta$ leading to the inhibition of the $\mathrm{T}$ cell response. Activation of dendritic cells (DC) by AhR agonists formylindolo[3,2-b]carbazole (FICZ) or synthetic [4-(3-chloro-phenyl)pyrimidin-2-yl]-[4-trifluoromethyl-phenyl]-amine (VAF347) impairs their ability to generate functional Th cells through a reduction of IL-6 secretion and of stimulatory molecules CD86 and HLA-DR expression. Altogether, AhR expression by epithelial cells, MSC and DC have a beneficial effect on asthma features.

Table 2. Direct Effects of AhR ligands on T cells in experimental asthma models.

\begin{tabular}{|c|c|c|c|}
\hline Experimental Model & AhR Ligand & T Cell Response & Ref \\
\hline $\begin{array}{l}\text { Non-eosinophilic } \\
\text { asthma model }\end{array}$ & $\begin{array}{c}2,3,7 \\
\text { 8-tetrachlorodibenzo-p-dioxin } \\
\text { (TCDD) }\end{array}$ & $\begin{array}{c}\text { Treg induction and inhibition of } \\
\text { Th17 activation. }\end{array}$ & [21] \\
\hline $\begin{array}{l}\text { Ozone induced airway } \\
\text { inflammation }\end{array}$ & Lipoxin A4 & Inhibition of Th17/22 response & [20] \\
\hline $\begin{array}{l}\text { Ovalbumin-induced } \\
\text { allergic asthma }\end{array}$ & $\begin{array}{l}\text { Indoxyl 3-sulfate (I3S) } \\
\text { 4-nonylphenol } \\
\text { Indeno[1,2,3-cd]pyrene }\end{array}$ & $\begin{array}{l}\text { Inhibition of Th2 differentiation } \\
\text { Increased secretion of } \\
\text { Th2 cytokines }\end{array}$ & $\begin{array}{c}{[14]} \\
{[28,29]}\end{array}$ \\
\hline $\begin{array}{l}\text { House Dust } \\
\text { Mite-induced } \\
\text { allergic asthma }\end{array}$ & $\begin{array}{c}\text { Benzo(a)pyrene }(\mathrm{B}(\mathrm{a}) \mathrm{P}) \text { or } \\
\text { particle matter } 2.5 \mu \mathrm{m}\left(\mathrm{PM}_{2.5}\right)\end{array}$ & $\begin{array}{l}\text { Increased secretion of Th } 2 \text { but } \\
\text { not Th1 or Th17 cytokines }\end{array}$ & {$[26,32]$} \\
\hline $\begin{array}{l}\text { Cockroach-sensitized } \\
\text { mouse model }\end{array}$ & $\mathrm{PM}_{2.5}$ & $\begin{array}{c}\text { Increased Th17 cells and } \\
\text { decreased Foxp3 regulatory } \\
\text { T cells }\end{array}$ & [35] \\
\hline
\end{tabular}




\section{AhR and Its Deleterious Effects in Experimental Asthma}

\subsection{AhR Increases Allergic Airway Inflammation by Activating Lung Epithelial Cells and Fibroblasts}

Airway epithelial cells are able to modulate allergic airway inflammation by their ability to produce a variety of inflammatory mediators including the alarmins IL-33, IL-25 and TSLP, critical for driving type 2 inflammation in the lung tissue. In the human bronchial epithelial cell line BEAS2B, TSLP expression is induced by particle matter (PM) with a diameter $<2.5 \mu \mathrm{m}\left(\mathrm{PM}_{2.5}\right)$ in an AhR-dependent pathway [93]. These data are in agreement with the ability of AhR to bind alarmin promoters and activate their transcription [30]. Interestingly, in vitro co-exposure of human epithelial cell lines to the HDM allergen Dermatophagoides farinae (Der f) and Benzo(a)pyrene (B(a)P), increases the expression of TSLP and IL-33 compared to cells stimulated with one or the other compound, effect also observed in vivo [26,27]. Moreover, Wang et al. have shown that pre-incubation of epithelial cells with the AhR inhibitor $\mathrm{CH} 223191$ or transfection with a siRNA targeting the AhR decreases the expression of both cytokines, through effects on reactive oxygen species (ROS) production. Indeed, CH223191 inhibits ROS production and pre-treatment with the antioxidant N-acetyl-L-cysteine alleviates the secretion of TSLP and IL-33. In this study, results were confirmed in vivo in a mouse model of Der $\mathrm{f} 1$ sensitization [26]. These studies suggest that AhR-dependent increased expression of alarmins by the lung epithelium may participate in the exacerbation of type 2 asthma by pollution.

Release of these epithelial alarmins can also activate ILC2 and while at the lung level, some AhR inducers such as diesel exhaust particles (DEP) and ozone [20] have been shown to enhance pulmonary ILC2 [31,94], the involvement of Ahr has not been evaluated. However, a recent study has shown that lung ILC2 that express the Il-33 receptor, produce IL-17 in response to in vivo papain challenge and that their production of Il-17, but not Il-5, is decreased in Ahr deficient mice [95] suggesting that Ahr in epithelial cells may also modulate Th17-type inflammation through ILC.

Another factor secreted by epithelial cells is mucin-containing mucus, which normally protects the airway from exogenous substances. Asthma is characterized by mucus hypersecretion by airway secretory club cells. These cells are very sensitive to AhR stimulation [22]. Wong et al. have reported that TCDD and urban dust increase the expression of the mucin gene MUC5AC via AhR signalling in a club cell line. Moreover, in vivo, a single intraperitoneal injection of TCDD increases Muc5ac, and the lung matrix metalloproteases (Mmp)12 and Mmp13, involved in tissue remodelling. Mice exhibiting an inhibitory mutation of $\mathrm{Ahr}\left(\mathrm{Ahr}{ }^{\mathrm{NLS}}\right.$, defective translocation to the nucleus) do not show such increased expression [22]. In HDM-sensitized mice, the addition of PM is also able to increase mucus production and Muc5ac expression in the lung, compared with HDM alone [32]. The mechanism has been further deciphered by Wang et al., who have shown in a mouse model of Der $\mathrm{f} 1$-sensitized mice, that the additional B(a)P increased goblet cell hyperplasia occurs through an Ahr-dependent pathway [26].

Fibroblasts are important structural cells of the lung implicated in matrix protein production such as collagen or profibrotic cytokines such as TGF- $\beta 1$. These cells are precursors for myofibroblasts involved in airway remodelling in asthma. The proliferation and the over-production of matrix mediators lead to a thickening of the airway wall and a decrease of the lumen. The WI-38 human lung fibroblast cell line constitutively expresses AhR. The treatment of these fibroblasts with cockroach allergen increases AhR and TGF- $\beta 1$ expression. Interestingly, cockroach allergen-induced TGF- $\beta 1$ is partly dependent on AhR activation since fibroblasts transfected with siRNA against AhR display lower expression of the cytokine compared to cells transfected with scrambled siRNA [23]. Moreover, costimulation of cockroach allergen-stimulated fibroblasts with the AhR agonist TCDD further enhances TGF- $\beta 1$ expression, through an increase in latent TGF- $\beta 1$ binding protein- 1 , which is inhibited by the AhR antagonist $\mathrm{CH} 223191$ [23]. In addition, cockroach allergen exposure of fibroblasts significantly increases the expression of alpha smooth muscle actin ( $\alpha$-SMA) also partly inhibited by $A h R$ siRNA, suggesting that AhR induces fibroblast differentiation towards myofibroblasts, cells implicated in subepithelial fibrosis and airway remodelling in asthma. Su et al. have also shown that TCDD alone induces AhR-dependent $\alpha$-SMA expression and migration of human HFL-1 fibroblasts [24]. Altogether, 
these results suggest that AhR may be a positive regulator of cockroach allergen-induced TGF- $\beta 1$ signalling in human fibroblasts and that AhR exogenous ligands can enhance airway remodelling.

These data highlight the difference of effects of TCDD in asthma according to the cell type expressing AhR, beneficial when involving DC and Treg cells and deleterious for epithelial cells and fibroblasts.

\subsection{AhR Activation Induces Dysregulation of Antigen Presenting Cells in Asthma}

DC and macrophages are antigen-presenting cells that play a major role in priming adaptive immune responses. A major compound of $\mathrm{PM}_{2.5}$, the indeno[1,2,3-cd]pyrene, structurally similar to $\mathrm{B}(\mathrm{a}) \mathrm{P}$, has been shown to increase type 2 inflammation in a mouse model of asthma. This exacerbation of the Th2 response was dependent on Ahr activation in DC, as shown in DC-specific Ahr knock out mice [28]. An exacerbating effect of vehicular ultrafine PM has also been observed in allergic airway inflammation in mice, by activation of the Ahr signalling cascade in DC, leading to elevated Il-17 responses in vivo as well as in vitro [33,34]. Mechanistically, costimulation of OVA-pulsed bone marrow derived-DC (BMDC) with $\mathrm{PM}_{2.5}$, induces Ahr-dependent increased activation of DC with increased expression of CD86 and MHC II, as well as of IL-1 $\beta$ compared to OVA stimulation alone [33]. Moreover, in co-cultures of OVA-specific DO11.10 T cell/OVA-pulsed DC with ultrafine particles (UFP), inhibition of Ahr induces a reduction in the secretion of Th2 and Th17 cytokines [34]. In vivo, exacerbation of the allergic response and Il-17 secretion by vehicular UFP, is mediated through a pathway involving Ahr-Jag1-Notch signalling in DC. More specifically, this induction is dependent on the activation of Ahr by PM-associated polycyclic aromatic hydrocarbons (PAH), which bind to the promoter of Jag1 and induce its transcriptional activation. Then, Jag1 engages Notch receptors on allergen-specific T cells, leading to increased differentiation into Th2 and Th17 cells. Deletion of Ahr in lineage-specific $\mathrm{CD} 11 \mathrm{c}^{+}$cells confers protection against PM-mediated exacerbation of the allergic response and PM-mediated IL-17 increase, highlighting the key role of Ahr in CD11 $\mathrm{c}^{+}$cells, and in particular DC, in the polarization of the allergic reaction aggravated by UPF [34].

In addition to DC, lung macrophages have also been implicated in the uptake and response to PM [96]. Inflammatory stimuli, including allergens, alter the potency of lung macrophages as antigen-presenting cells, and exposure of macrophages to PM alters their function. Xia et al., have shown that the major targets of nano-sized particles in the mouse lung are macrophages [36]. In bone marrow derived-macrophages (BMDM), stimulation with $\mathrm{PM}_{2.5}$ induces Ahr-dependent increased expression of oxidative stress enzyme Heme-oxygenase 1 as well as of inflammatory cytokines Il- 6 and Il-1 $\beta$ independently of OVA stimulation. Interestingly, co-exposure of BMDM to OVA and PM increases Ccxl2 in an Ahr-dependent manner [33]. This chemokine induced by IL-17 is a chemoattractant for neutrophils but also for airway smooth muscle cells [97]. B(a)P also triggers the expression of neutrophil attracting chemokines, as shown in human macrophages by the induction of CXCL8 through the binding of AhR to the XRE sequence on the CXCL8 promoter. In mice, $\mathrm{B}(\mathrm{a}) \mathrm{P}$ intranasal instillation also increases Cxcl1 and Il-6 as well as neutrophil recruitment in broncho-alveolar lavages [98]. These observations support the implication of AhR dependent pollutant-activated macrophages in severe asthma associated with neutrophilia and airway remodelling. Among lung macrophages in steady-state conditions, $95 \%$ of the particles are internalized by alveolar macrophages (AM) while only 2 to $3 \%$ are internalized by interstitial macrophages (IM). In OVA-sensitized mice, this ratio is modified with an internalisation of $70 \%$ and $30 \%$ respectively [36]. As it was described previously for DC, the Ahr-Jag1-Notch pathway has been explored in macrophages and it has been shown that, in vitro, particularly in AM compared to IM or DC, UFP upregulate Jag1 expression, which is abolished by deletion of $A h r$ in myeloid lineage-specific $\mathrm{CD} 11 \mathrm{c}^{+}$cells. Similar results were obtained in vivo in OVA sensitized mice [36]. AM capacity to induce T cell polarization was analysed in vitro. Purified mouse AM stimulated with OVA alone induced increased proportions of $\mathrm{T}$ helper cells producing Il-17, Il-13 or Il-4 as well as 40\% of Foxp $3^{+}$induced T regulatory cells (iTreg) and a small proportion of Ifn- $\gamma^{+}$Th1 cells. In UFP/OVA coexposure, Th2 and Th17 polarization was enhanced whereas iTreg and 
Th1 were inhibited. The UFP effect on OVA stimulated macrophages was completely abolished in Jag $1^{--}$cells [36]. These data suggest that as in DC, Ahr regulates Jag1 transcription in AM and increases Th2/Th17 cytokines, while iTreg are inhibited.

All these observations demonstrate an important role of AhR ligands from pollution in the dysregulation of antigen presenting cells in asthma leading to increased inflammation and severity of the disease. Here again, the same cells, i.e., DC, are involved in both beneficial and deleterious effects of AhR in allergic inflammation, yet involving different AhR ligands, suggesting that their affinity, and potentially their access to the transcriptional AhR targets, may modify the DC response.

\subsection{AhR Ligands Increase Pathologic T Cell and Asthma Features}

Antigen-presenting cell dysregulation by AhR-binding pollutants induces aberrant $\mathrm{T}$ cell responses particularly an increased Th2/Th17 pattern as described in the previous paragraph. In vitro studies have shown that AhR ligands can also act directly on T cells. Van Voorhis et al. have shown that ambient urban PM promotes Th17 polarization in vitro in an Ahr dependent way in mice [99]. These results have been further confirmed in mice and in humans. Indeed, a recent study has evaluated the in vitro effect of $\mathrm{PM}_{2.5}$ exposure on the differentiation of Th17 or Treg from either $\mathrm{CD} 4^{+} \mathrm{T}$ cells from mouse spleen or from human peripheral blood mononuclear cells. The authors found increased Th17 and decreased Treg differentiation dependent on AhR but independent of the presence of antigen-presenting cells [35]. In contrast, in a study using another AhR ligand, the coculture of mouse T cells with OVAand PAH 4-nonylphenol -activated BMDC did not modulate Il-17 and Il-4, whereas Ifn- $\gamma$ was largely inhibited compared to cocultures with BMDC activated with OVA alone leading to a dysregulation of the Th1/Th2 balance [29]. This discrepancy between studies may be explained by the presence or not of antigen-presenting cell secreting factors that modulate $\mathrm{T}$ cell differentiation, compared to less specific direct $\mathrm{T}$ cell activation and differentiation in the presence of anti-CD3/CD28 antibodies. Moreover, AhR activation in the two first studies was mediated by $\mathrm{PM}_{2.5}$, which contain multiple $\mathrm{PAH}$ as potential ligands of AhR, whereas the last study used the single pure 4-nonylphenol PAH. Therefore, differentiation towards a particular Th profile may result from the integration of multiple signals absent in single PAH activation.

Similar contrasting results have been observed in vivo using different allergens. In Der $\mathrm{f}$ 1-sensitized mice, increased secretion of Th2, but not Th1 or Th17 cytokines, has been observed in the broncho-alveolar lavage of mice co-exposed with $\mathrm{B}(\mathrm{a}) \mathrm{P}$, compared to Der $\mathrm{f} 1$ alone. The inhibition of Ahr with the specific CH223191 inhibitor abolished this effect on Th2 cytokines [26]. Castañeda et al. have observed similar results using total $\mathrm{HDM}$ extract and ambient $\mathrm{PM}_{2.5}$, with increases in Th2 but no differences in Th17 cytokines in the lung of co-exposed mice [32]. However, they did not explore the implication of Ahr. In another model of mice sensitized with OVA and the 4-nonylphenol or the indeno[1,2,3-cd]pyrene, Th2 cytokines were also increased in the lung of mice in an Ahr-dependent pathway $[28,29]$. In contrast, in a cockroach-sensitized mouse model, co-exposure with $\mathrm{PM}_{2.5}$ increased $\mathrm{CD}^{+} \mathrm{Il}^{-17^{+}} \mathrm{T}$ cells in lymph nodes while $\mathrm{CD} 4^{+} \mathrm{FoxP}^{+}$cells were decreased. Moreover, this co-exposure increased Il-17, Ror $\gamma t$ and Il-4 expression in the lung whereas Foxp3 was decreased and Ifn- $\gamma$ was not modified showing a dysregulation in the balance between Th17 and Treg. This dysregulation was $\mathrm{T}$ cell/Ahr-dependent since mice deficient in $\mathrm{Ahr}$ in $\mathrm{CD}^{+}$cells displayed low $\mathrm{Il}-17$ and increased Foxp3 levels in the lung [35]. To explain these findings a glycolysis related molecular mechanism was proposed. It has been previously shown that glycolysis regulates Th17 cell differentiation [100] whereas Treg are regulated by Tet methylcytosine dioxygenase-induced demethylation on the Foxp3 promoter. In the cockroach model, the expression of the enzymes of the glycolytic pathway, as well as the glycolysis rate, were increased in $\mathrm{PM}_{2.5}$-stimulated Th17 cells [35]. This effect was mediated by the regulator of glycogenesis Hif- $1 \alpha$, as demonstrated by inhibition of Th17 differentiation in Hif- $1 \alpha$ knockdown T cells. Hif- $1 \alpha$ was also induced by $\mathrm{PM}_{2.5}$ in Treg, but the knockout had no effect on the decrease of Treg differentiation in vitro suggesting a different mechanism of regulation by Ahr. Indeed, in this same study, it was also demonstrated that Ahr bind to the promoter of Got1, the major 
transaminase catalysing the conversion of glutamate to a-ketoglutaric acid in T cells. Knockdown of Got1 promoted the differentiation of Treg cells and rescued the inhibitory effect of $\mathrm{PM}_{2.5}$ on their differentiation. Finally, $\mathrm{PM}_{2.5}$ exposure upregulated Got1 expression through Ahr, resulting in inhibition of Tet-2 activity and hypermethylation in the Foxp3 locus, thereby impairing Treg differentiation [35]. Therefore, these data suggest that the different effects of the AhR ligands observed in vivo, are linked to epigenetic mechanisms that may vary according to the allergen used for the asthma model.

The deleterious effects of AhR activation in asthma are summarized in Figure 4, except for AhR ligand direct effects on $\mathrm{T}$ cells, which are shown in Table 2.

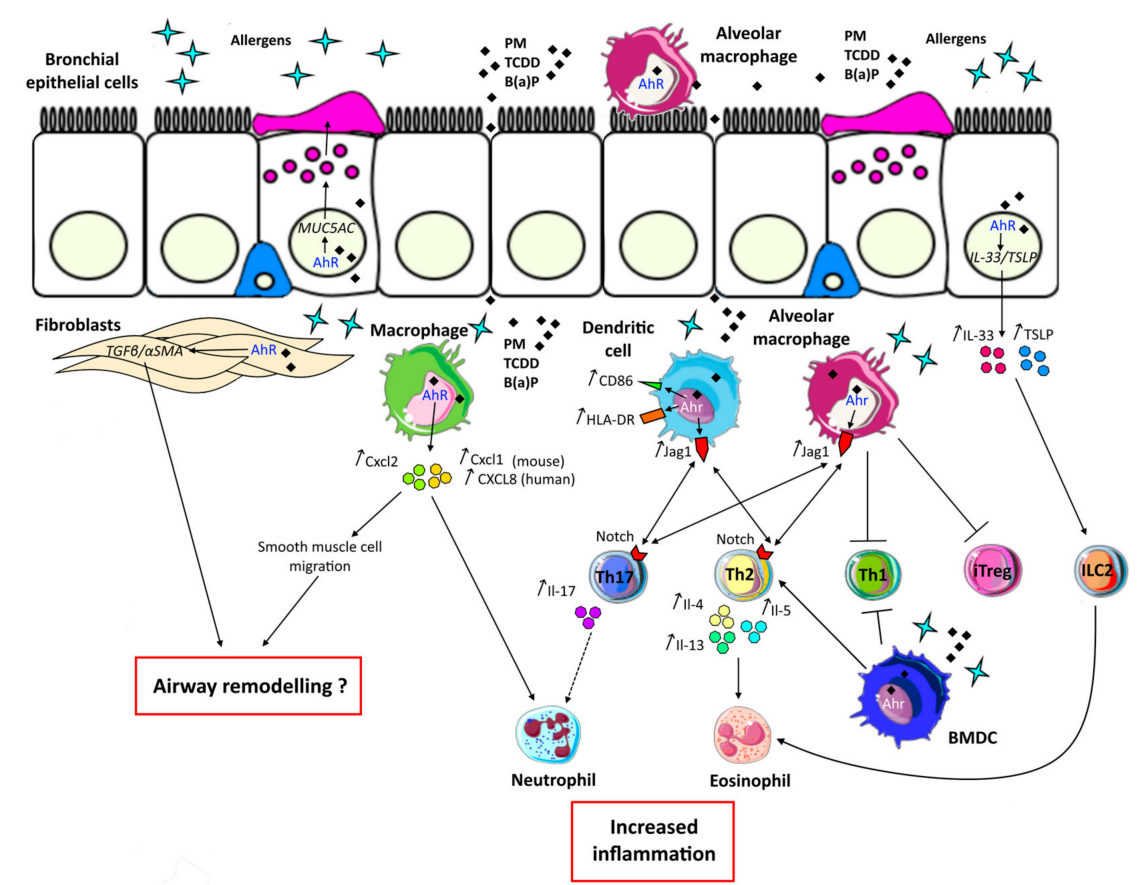

Figure 4. Deleterious effects of aryl hydrocarbon receptor (AhR) activation in asthma. Bronchial epithelial cells are the first barrier against environmental agents. In asthma, exposure to allergens and environmental AhR ligands such as particulate matter (PM), 2,3,7,8-tetrachlorodibenzo-p-dioxin (TCDD) or Benzo(a)pyrene (B(a)P) induces MUC5AC expression leading to mucus hypersecretion through AhR. Moreover, the alarmins interleukin (IL)-33 and Thymic Stromal Lymphopoietin (TSLP) are also induced through this pathway. These cytokines are able to activate innate lymphoid cells type 2 (ILC2) inducing eosinophil recruitment. Other structural cells implicated in asthma and expressing AhR are fibroblasts. Co-activation of these cells by an allergen and AhR ligands leads to TGF- $\beta$ and $\alpha$-SMA transcription, which are implicated in airway remodelling. Bone marrow derived-macrophages (BMDM) can also participate in airway remodelling through secretion of $\mathrm{Cxcl} 2$, a chemokine induced by Ahr activation and leading to smooth muscle cell migration. Moreover, increased secretion of $\mathrm{Cxcl} 2$ as well as $\mathrm{Cxcl} 1$ (or CXCL-8/IL-8 in humans) in response to allergen and AhR ligands costimulation leads to the recruitment of neutrophils. Neutrophil inflammation is associated with severe asthma and increased secretion of IL-17. The Th17 pathway is also induced by allergens and AhR ligands activated -dendritic cells and -alveolar macrophages through increased Jag1 expression. Furthermore, alveolar macrophages are implicated in Th1 and induced T regulatory cell (iTreg) inhibition through Ahr activation. In response to Ahr signalling, dendritic cells through increased expression of costimulatory molecule CD86 and HLA-DR, as well as alveolar macrophages participate in increased Thelper (Th)2 activation. Moreover, bone marrow derived-dendritic cells (BMDC) stimulated with an allergen and AhR ligands can amplify type 2 responses by inhibiting Th1 and activating Th2 cells. All these AhR-dependent signals result in increased Th17/neutrophilic and/or Th2/ILC2/eosinophilic inflammation, together with decreased Th1/Treg regulation. 
From what has been discussed in this section we can conclude that many exogenous AhR ligands derived from pollutants, in particular PM and PAH, increase asthma features in animal models. In particular, inflammatory cell infiltration mostly eosinophils and/or neutrophils, inflammatory cytokine secretion, mucus production, airway hyperreactivity and IgE production are increased. Some differences are observed regarding the polarization profile, which may be related to the allergen and its composition, or to the AhR-expressing cell type initially activated. Regarding the differences in the effects of AhR on airway allergic inflammation, variations in ligands binding affinity and the cell types involved may explain the observed discrepancies.

\section{AhR in Asthma Patients}

Asthma patients display heterogeneous features including the type 2 eosinophilic and the non type 2 neutrophilic Th17 endotypes [13]. Surprisingly, few studies have evaluated AhR in samples from asthmatic patients. In peripheral mononuclear cells from uncontrolled allergic asthmatics, AhR and IL-22 mRNA expression are increased compared with controlled asthma and healthy subjects, suggesting a relationship with asthma control [101]. A recent study has shown that bronchial epithelial cells derived from allergic asthmatic patients and stimulated with DEP produce Th2-inducing cytokines such as IL-33, IL-25 and TSLP, in an AhR-dependent manner. Moreover, severe asthmatic patients that exhibit high AhR nuclear translocation, have the highest levels of these type 2-inducing cytokines [30], indicating a link between $\mathrm{AhR}$ and severe allergic asthma. An increased expression of AhR has also been observed in fibroblasts from asthmatic patients compared to healthy donors [23], suggesting a potential participation in airway remodelling. In allergic asthmatic patients, it has been observed that the expression of IL-22 and IL-17, as well as the AhR target gene CYP1A1, in peripheral mononuclear cells is increased compared with healthy controls. However, stimulation with DEP increases AhR-dependent IL-22 production by $\mathrm{CD}^{+}$cells while decreasing IL-17 [66], implying that AhR differentially affects IL-17 and IL-22 production by mononuclear cells in humans as compared to mice. These variations could be related to species-specific effects of AhR agonists. Indeed, differences in ligand affinity have been observed between mouse and human AhR [102]. These affinity differences will have to be considered regarding the putative therapeutic applications in humans.

\section{Conclusions}

Taken together, all these data underpins the complexity of the AhR pathway, which leads to both beneficial and deleterious outcomes in asthma. The different outcomes can be explained by the ligand used and its affinity for AhR, the dose and the duration of AhR activation [25], by the cell subsets targeted and their plasticity, by the tissue involved and its local inflammatory environment, and by the accessibility of AhR transcriptional targets. For example, it was shown that microglial AhR exerts both pro-inflammatory and anti-inflammatory effects on the regulation of LPS-induced neuroinflammation, depending on the availability of external AhR ligands [103]. Such a mechanism could also occur in the lung but there are still many unknowns, which need to be solved before starting therapeutic manipulation of the receptor in a cell- or lung-specific manner. However, it is noteworthy that for the skin, drugs targeting AhR have been developed for the treatment of atopic dermatitis, an allergic disease characterized by a type 2 cytokine profile and recently described as elicited by pollutants through AhR [104]. Recent clinical trials using Tapinarof cream, an AhR activator, have shown encouraging preliminary results in atopic dermatitis [44,45] suggesting that AhR may represent a therapeutic target in allergic diseases.

Author Contributions: Conceptualization, A.T., O.P.-G. and P.d.N.; writing-review and editing, O.P.-G., M.B., J.C., D.A.-S., A.T., and P.d.N.; funding acquisition, A.T. All authors have read and agreed to the published version of the manuscript.

Funding: This research was funded by Santelys, Fonds de recherche en Santé Respiratoire, PTR (18-16) from Institut Pasteur and by ANR 18-CE14-0020, and the APC was funded by Inserm.

Conflicts of Interest: The authors declare no conflict of interest. 


\section{Abbreviations}

$\begin{array}{ll}\text { AhR } & \text { Aryl hydrocarbon Receptor } \\ \text { AM } & \text { Alveolar macrophages } \\ \text { BMDC } & \text { Bone marrow-derived dendritic cells } \\ \text { BMDM } & \text { Bone marrow-derived macrophages } \\ \text { Breg } & \text { B regulatory cells } \\ \text { CCL } & \text { (C-C motif) ligand } \\ \text { DC } & \text { Dendritic cells } \\ \text { DEP } & \text { Diesel exhaust particles } \\ \text { Der f } & \text { Dermatophagoides farinae } \\ \text { FICZ } & \text { 6-Formylindolo[3,2-b]carbazole } \\ \text { Foxp3 } & \text { Forkhead box P3 } \\ \text { HDM } & \text { House dust mite } \\ \text { iTreg } & \text { Induced T regulatory cells } \\ \text { IL- } & \text { Interleukin } \\ \text { ILC } & \text { Innate lymphoid cells } \\ \text { IM } & \text { Interstitial macrophages } \\ \text { IRF4 } & \text { Interferon regulatory factor 4 } \\ \text { LPS } & \text { Lipopolysaccharide } \\ \text { MMP } & \text { Matrix metalloproteinase } \\ \text { MSC } & \text { Mesenchymal stem cells } \\ \text { NO } & \text { Nitric oxide } \\ \text { OVA } & \text { Ovalbumin } \\ \text { PAH } & \text { Poly aromatic hydrocarbons } \\ \text { PM } & \text { Particle matters } \\ \text { ROS } & \text { Reactive oxygen species } \\ \text { SMA } & \text { Smooth muscle actin } \\ \text { STAT } & \text { Signal transducer and activator of transcription } \\ \text { TET } & \text { Ten-eleven translocation } \\ \text { TGF- } \beta & \text { Transforming growth factor- } \beta \\ \text { Th } & \text { T helper } \\ \text { Treg } & \text { T regulatory cells } \\ \text { Tr1 } & \text { Type } 1 \text { T regulatory cells } \\ \text { TSLP } & \text { Thymic stromal lymphopoietin } \\ \text { UFP } & \text { Ultrafine particles } \\ \text { TCDD } & \text { 2,3,7,8-tetrachlorodi-p-dioxin } \\ \text { WT } & \text { Wild type } \\ & \end{array}$

\section{References}

1. Tsicopoulos, A.; De Nadaï, P.; Glineur, C. Environmental and genetic contribution in airway epithelial barrier in asthma pathogenesis. Curr. Opin. Allergy Clin. Immunol. 2013, 13, 495-499. [CrossRef] [PubMed]

2. Choudhary, D.; Jansson, I.; Schenkman, J.; Sarfarazi, M.; Stoilov, I. Comparative expression profiling of 40 mouse cytochrome P450 genes in embryonic and adult tissues. Arch. Biochem. Biophys. 2003, 414, 91-100. [CrossRef]

3. Hayashi, S.; Watanabe, J.; Nakachi, K.; Eguchi, H.; Gotoh, O.; Kawajiri, K. Interindividual difference in expression of human Ah receptor and related P450 genes. Carcinogenesis 1994, 15, 801-806. [CrossRef] [PubMed]

4. Gutierrez-Vazquez, C.; Quintana, F.J. Regulation of the Immune Response by the Aryl Hydrocarbon Receptor. Immunity 2018, 48, 19-33. [CrossRef]

5. Larigot, L.; Juricek, L.; Dairou, J.; Coumoul, X. AhR signaling pathways and regulatory functions. Biochim. Open 2018, 7, 1-9. [CrossRef]

6. Rothhammer, V.; Quintana, F.J. The aryl hydrocarbon receptor: An environmental sensor integrating immune responses in health and disease. Nat. Rev. Immunol. 2019, 19, 184-197. [CrossRef] 
7. Guyot, E.; Chevallier, A.; Barouki, R.; Coumoul, X. The AhR twist: Ligand-dependent AhR signaling and pharmaco-toxicological implications. Drug Discov. Today 2013, 18, 479-486. [CrossRef]

8. Moura-Alves, P.; Fae, K.; Houthuys, E.; Dorhoi, A.; Kreuchwig, A.; Furkert, J.; Barison, N.; Diehl, A.; Munder, A.; Constant, P.; et al. AhR sensing of bacterial pigments regulates antibacterial defence. Nature 2014, 512, 387-392. [CrossRef]

9. Xu, T.; Zhou, Y.; Qiu, L.; Do, D.C.; Zhao, Y.; Cui, Z.; Wang, H.; Liu, X.; Saradna, A.; Cao, X.; et al. Aryl Hydrocarbon Receptor Protects Lungs from Cockroach Allergen-Induced Inflammation by Modulating Mesenchymal Stem Cells. J. Immunol. 2015, 195, 5539-5550. [CrossRef]

10. Zelante, T.; Iannitti, R.G.; Cunha, C.; De Luca, A.; Giovannini, G.; Pieraccini, G.; Zecchi, R.; D'Angelo, C.; Massi-Benedetti, C.; Fallarino, F.; et al. Tryptophan catabolites from microbiota engage aryl hydrocarbon receptor and balance mucosal reactivity via interleukin-22. Immunity 2013, 39, 372-385. [CrossRef]

11. Amakura, Y.; Tsutsumi, T.; Sasaki, K.; Yoshida, T.; Maitani, T. Screening of the inhibitory effect of vegetable constituents on the aryl hydrocarbon receptor-mediated activity induced by 2,3,7,8tetrachlorodibenzo-p-dioxin. Biol. Pharm. Bull. 2003, 26, 1754-1760. [CrossRef] [PubMed]

12. Chiaro, C.R.; Patel, R.D.; Perdew, G.H. 12(R)-Hydroxy-5(Z),8(Z),10(E),14(Z)-eicosatetraenoic acid [12(R)-HETE], an arachidonic acid derivative, is an activator of the aryl hydrocarbon receptor. Mol. Pharmacol. 2008, 74, 1649-1656. [CrossRef] [PubMed]

13. Phelan, D.; Winter, G.M.; Rogers, W.J.; Lam, J.C.; Denison, M.S. Activation of the Ah receptor signal transduction pathway by bilirubin and biliverdin. Arch. Biochem. Biophys. 1998, 357, 155-163. [CrossRef] [PubMed]

14. Hwang, Y.J.; Yun, M.O.; Jeong, K.T.; Park, J.H. Uremic toxin indoxyl 3-sulfate regulates the differentiation of Th2 but not of Th1 cells to lessen allergic asthma. Toxicol. Lett. 2014, 225, 130-138. [CrossRef]

15. Mezrich, J.D.; Fechner, J.H.; Zhang, X.; Johnson, B.P.; Burlingham, W.J.; Bradfield, C.A. An interaction between kynurenine and the aryl hydrocarbon receptor can generate regulatory T cells. J. Immunol. 2010, 185, 3190-3198. [CrossRef]

16. Sibilano, R.; Frossi, B.; Calvaruso, M.; Danelli, L.; Betto, E.; Dall'Agnese, A.; Tripodo, C.; Colombo, M.P.; Pucillo, C.E.; Gri, G. The aryl hydrocarbon receptor modulates acute and late mast cell responses. J. Immunol. 2012, 189, 120-127. [CrossRef]

17. Thatcher, T.H.; Williams, M.A.; Pollock, S.J.; McCarthy, C.E.; Lacy, S.H.; Phipps, R.P.; Sime, P.J. Endogenous ligands of the aryl hydrocarbon receptor regulate lung dendritic cell function. Immunology 2016, 147, 41-54. [CrossRef]

18. Jeong, K.T.; Hwang, S.J.; Oh, G.S.; Park, J.H. FICZ, a tryptophan photoproduct, suppresses pulmonary eosinophilia and Th2-type cytokine production in a mouse model of ovalbumin-induced allergic asthma. Int. Immunopharmacol. 2012, 13, 377-385. [CrossRef]

19. Schaldach, C.M.; Riby, J.; Bjeldanes, L.F. Lipoxin A4: A new class of ligand for the Ah receptor. Biochemistry 1999, 38, 7594-7600. [CrossRef]

20. Michaudel, C.; Bataille, F.; Maillet, I.; Fauconnier, L.; Colas, C.; Sokol, H.; Straube, M.; Couturier-Maillard, A.; Dumoutier, L.; van Snick, J.; et al. Ozone-Induced Aryl Hydrocarbon Receptor Activation Controls Lung Inflammation via Interleukin-22 Modulation. Front. Immunol. 2020, 11, 144. [CrossRef]

21. Li, X.M.; Peng, J.; Gu, W.; Guo, X.J. TCDD-Induced Activation of Aryl Hydrocarbon Receptor Inhibits Th17 Polarization and Regulates Non-Eosinophilic Airway Inflammation in Asthma. PLoS ONE 2016, 11, e0150551. [CrossRef]

22. Wong, P.S.; Vogel, C.F.; Kokosinski, K.; Matsumura, F. Arylhydrocarbon receptor activation in NCI-H441 cells and C57BL/6 mice: Possible mechanisms for lung dysfunction. Am. J. Respir. Cell Mol. Biol. 2010, 42, 210-217. [CrossRef]

23. Zhou, Y.; Mirza, S.; Xu, T.; Tripathi, P.; Plunkett, B.; Myers, A.; Gao, P. Aryl Hydrocarbon Receptor (AhR) Modulates Cockroach Allergen-Induced Immune Responses through Active TGF $\beta 1$ Release. Mediat. Inflamm. 2014, 2014, 1-13. [CrossRef]

24. Su, H.H.; Lin, H.T.; Suen, J.L.; Sheu, C.C.; Yokoyama, K.K.; Huang, S.K.; Cheng, C.M. Aryl hydrocarbon receptor-ligand axis mediates pulmonary fibroblast migration and differentiation through increased arachidonic acid metabolism. Toxicology 2016, 370, 116-126. [CrossRef] 
25. Ehrlich, A.K.; Pennington, J.M.; Bisson, W.H.; Kolluri, S.K.; Kerkvliet, N.I. TCDD, FICZ, and Other High Affinity AhR Ligands Dose-Dependently Determine the Fate of CD4+ T Cell Differentiation. Toxicol. Sci. 2018, 161, 310-320. [CrossRef]

26. Wang, E.; Liu, X.; Tu, W.; Do, D.C.; Yu, H.; Yang, L.; Zhou, Y.; Xu, D.; Huang, S.K.; Yang, P.; et al. Benzo(a)pyrene facilitates dermatophagoides group 1 (Der $\mathrm{f} 1$ )-induced epithelial cytokine release through aryl hydrocarbon receptor in asthma. Allergy 2019, 74, 1675-1690. [CrossRef]

27. Tajima, H.; Tajiki-Nishino, R.; Watanabe, Y.; Kurata, K.; Fukuyama, T. Activation of aryl hydrocarbon receptor by benzo[a]pyrene increases interleukin 33 expression and eosinophil infiltration in a mouse model of allergic airway inflammation. J. Appl. Toxicol. 2020, 40, 1545-1553. [CrossRef]

28. Wong, T.H.; Lee, C.L.; Su, H.H.; Lee, C.L.; Wu, C.C.; Wang, C.C.; Sheu, C.C.; Lai, R.S.; Leung, S.Y.; Lin, C.C.; et al. A prominent air pollutant, Indeno[1,2,3-cd]pyrene, enhances allergic lung inflammation via aryl hydrocarbon receptor. Sci. Rep. 2018, 8, 5198. [CrossRef]

29. Suen, J.L.; Hsu, S.H.; Hung, C.H.; Chao, Y.S.; Lee, C.L.; Lin, C.Y.; Weng, T.H.; Yu, H.S.; Huang, S.K. A common environmental pollutant, 4-nonylphenol, promotes allergic lung inflammation in a murine model of asthma. Allergy 2013, 68, 780-787. [CrossRef]

30. Weng, C.M.; Wang, C.H.; Lee, M.J.; He, J.R.; Huang, H.Y.; Chao, M.W.; Chung, K.F.; Kuo, H.P. Aryl hydrocarbon receptor activation by diesel exhaust particles mediates epithelium-derived cytokines expression in severe allergic asthma. Allergy 2018, 73, 2192-2204. [CrossRef]

31. De Grove, K.C.; Provoost, S.; Hendriks, R.W.; McKenzie, A.N.J.; Seys, L.J.M.; Kumar, S.; Maes, T.; Brusselle, G.G.; Joos, G.F. Dysregulation of type 2 innate lymphoid cells and TH2 cells impairs pollutant-induced allergic airway responses. J. Allergy Clin. Immunol. 2017, 139, 246-257.e4. [CrossRef] [PubMed]

32. Castaneda, A.R.; Vogel, C.F.A.; Bein, K.J.; Hughes, H.K.; Smiley-Jewell, S.; Pinkerton, K.E. Ambient particulate matter enhances the pulmonary allergic immune response to house dust mite in a BALB/c mouse model by augmenting Th2- and Th17-immune responses. Physiol. Rep. 2018, 6, e13827. [CrossRef] [PubMed]

33. Castaneda, A.R.; Pinkerton, K.E.; Bein, K.J.; Magana-Mendez, A.; Yang, H.T.; Ashwood, P.; Vogel, C.F.A. Ambient particulate matter activates the aryl hydrocarbon receptor in dendritic cells and enhances Th17 polarization. Toxicol. Lett. 2018, 292, 85-96. [CrossRef] [PubMed]

34. Xia, M.; Viera-Hutchins, L.; Garcia-Lloret, M.; Noval Rivas, M.; Wise, P.; McGhee, S.A.; Chatila, Z.K.; Daher, N.; Sioutas, C.; Chatila, T.A. Vehicular exhaust particles promote allergic airway inflammation through an aryl hydrocarbon receptor-notch signaling cascade. J. Allergy Clin. Immunol. 2015, 136, 441-453. [CrossRef]

35. Sun, L.; Fu, J.; Lin, S.H.; Sun, J.L.; Xia, L.; Lin, C.H.; Liu, L.; Zhang, C.; Yang, L.; Xue, P.; et al. Particulate matter of 2.5 mum or less in diameter disturbs the balance of TH17/regulatory $\mathrm{T}$ cells by targeting glutamate oxaloacetate transaminase 1 and hypoxia-inducible factor 1alpha in an asthma model. J. Allergy Clin. Immunol. 2020, 145, 402-414. [CrossRef]

36. Xia, M.; Harb, H.; Saffari, A.; Sioutas, C.; Chatila, T.A. A Jagged 1-Notch 4 molecular switch mediates airway inflammation induced by ultrafine particles. J. Allergy Clin. Immunol. 2018, 142, 1243-1256.e17. [CrossRef]

37. Ettmayer, P.; Mayer, P.; Kalthoff, F.; Neruda, W.; Harrer, N.; Hartmann, G.; Epstein, M.M.; Brinkmann, V.; Heusser, C.; Woisetschlager, M. A novel low molecular weight inhibitor of dendritic cells and B cells blocks allergic inflammation. Am. J. Respir. Crit. Care Med. 2006, 173, 599-606. [CrossRef]

38. Lawrence, B.P.; Denison, M.S.; Novak, H.; Vorderstrasse, B.A.; Harrer, N.; Neruda, W.; Reichel, C.; Woisetschlager, M. Activation of the aryl hydrocarbon receptor is essential for mediating the anti-inflammatory effects of a novel low-molecular-weight compound. Blood 2008, 112, 1158-1165. [CrossRef]

39. Nakai, R.; Fukuda, S.; Kawase, M.; Yamashita, Y.; Ashida, H. Curcumin and its derivatives inhibit 2,3,7,8,-tetrachloro-dibenzo-p-dioxin-induced expression of drug metabolizing enzymes through aryl hydrocarbon receptor-mediated pathway. Biosci. Biotechnol. Biochem. 2018, 82, 616-628. [CrossRef]

40. Yang, T.; Feng, Y.L.; Chen, L.; Vaziri, N.D.; Zhao, Y.Y. Dietary natural flavonoids treating cancer by targeting aryl hydrocarbon receptor. Crit. Rev. Toxicol. 2019, 49, 445-460. [CrossRef]

41. Vrzal, R.; Frauenstein, K.; Proksch, P.; Abel, J.; Dvorak, Z.; Haarmann-Stemmann, T. Khellin and visnagin differentially modulate AHR signaling and downstream CYP1A activity in human liver cells. PLoS ONE 2013, 8, e74917. [CrossRef]

42. Zhao, B.; Degroot, D.E.; Hayashi, A.; He, G.; Denison, M.S. CH223191 is a ligand-selective antagonist of the Ah (Dioxin) receptor. Toxicol. Sci. 2010, 117, 393-403. [CrossRef] 
43. Henry, E.C.; Kende, A.S.; Rucci, G.; Totleben, M.J.; Willey, J.J.; Dertinger, S.D.; Pollenz, R.S.; Jones, J.P.; Gasiewicz, T.A. Flavone antagonists bind competitively with 2,3,7, 8-tetrachlorodibenzo-p-dioxin (TCDD) to the aryl hydrocarbon receptor but inhibit nuclear uptake and transformation. Mol. Pharmacol. 1999, 55, 716-725.

44. Paller, A.S.; Gold, L.S.; Soung, J.; Tallman, A.M.; Rubenstein, D.S.; Gooderham, M. Efficacy and Patient-Reported Outcomes from a Phase IIb, Randomized Clinical Trial of Tapinarof Cream for the Treatment of Adolescents and Adults with Atopic Dermatitis. J. Am. Acad. Dermatol. 2020. [CrossRef]

45. Peppers, J.; Paller, A.S.; Maeda-Chubachi, T.; Wu, S.; Robbins, K.; Gallagher, K.; Kraus, J.E. A phase 2, randomized dose-finding study of tapinarof (GSK2894512 cream) for the treatment of atopic dermatitis. J. Am. Acad. Dermatol. 2019, 80, 89-98.e3. [CrossRef]

46. Kuruvilla, M.E.; Lee, F.E.; Lee, G.B. Understanding Asthma Phenotypes, Endotypes, and Mechanisms of Disease. Clin. Rev. Allergy Immunol. 2019, 56, 219-233. [CrossRef]

47. Ray, A.; Raundhal, M.; Oriss, T.B.; Ray, P.; Wenzel, S.E. Current concepts of severe asthma. J. Clin. Investig. 2016, 126, 2394-2403. [CrossRef]

48. Goudot, C.; Coillard, A.; Villani, A.C.; Gueguen, P.; Cros, A.; Sarkizova, S.; Tang-Huau, T.L.; Bohec, M.; Baulande, S.; Hacohen, N.; et al. Aryl Hydrocarbon Receptor Controls Monocyte Differentiation into Dendritic Cells versus Macrophages. Immunity 2017, 47, 582-596.e6. [CrossRef]

49. Schedel, M.; Michel, S.; Gaertner, V.D.; Toncheva, A.A.; Depner, M.; Binia, A.; Schieck, M.; Rieger, M.T.; Klopp, N.; von Berg, A.; et al. Polymorphisms related to ORMDL3 are associated with asthma susceptibility, alterations in transcriptional regulation of ORMDL3, and changes in TH2 cytokine levels. J. Allergy Clin. Immunol. 2015, 136, 893-903.e814. [CrossRef]

50. Toncheva, A.A.; Potaczek, D.P.; Schedel, M.; Gersting, S.W.; Michel, S.; Krajnov, N.; Gaertner, V.D.; Klingbeil, J.M.; Illig, T.; Franke, A.; et al. Childhood asthma is associated with mutations and gene expression differences of ORMDL genes that can interact. Allergy 2015, 70, 1288-1299. [CrossRef]

51. Wang, H.C.; Wong, T.H.; Wang, L.T.; Su, H.H.; Yu, H.Y.; Wu, A.H.; Lin, Y.C.; Chen, H.L.; Suen, J.L.; $\mathrm{Hsu}$, S.H.; et al. Aryl hydrocarbon receptor signaling promotes ORMDL3-dependent generation of sphingosine-1-phosphate by inhibiting sphingosine-1-phosphate lyase. Cell Mol. Immunol. 2019, 16, 783-790. [CrossRef]

52. Ovrevik, J.; Lag, M.; Lecureur, V.; Gilot, D.; Lagadic-Gossmann, D.; Refsnes, M.; Schwarze, P.E.; Skuland, T.; Becher, R.; Holme, J.A. AhR and Arnt differentially regulate NF-kappaB signaling and chemokine responses in human bronchial epithelial cells. Cell Commun. Signal. 2014, 12, 48. [CrossRef]

53. Lambrecht, B.N.; Hammad, H. The immunology of the allergy epidemic and the hygiene hypothesis. Nat. Immunol. 2017, 18, 1076-1083. [CrossRef]

54. Robinson, D.S.; Hamid, Q.; Ying, S.; Tsicopoulos, A.; Barkans, J.; Bentley, A.M.; Corrigan, C.; Durham, S.R.; Kay, A.B. Predominant TH2-like bronchoalveolar T-lymphocyte population in atopic asthma. N. Engl. J. Med. 1992, 326, 298-304. [CrossRef]

55. McKenzie, A.N. Type-2 innate lymphoid cells in asthma and allergy. Ann. Am. Thorac. Soc. 2014, 11, S263-S270. [CrossRef]

56. Everaere, L.; Ait-Yahia, S.; Molendi-Coste, O.; Vorng, H.; Quemener, S.; LeVu, P.; Fleury, S.; Bouchaert, E.; Fan, Y.; Duez, C.; et al. Innate lymphoid cells contribute to allergic airway disease exacerbation by obesity. J. Allergy Clin. Immunol. 2016, 138, 1309-1318.e11. [CrossRef]

57. Kim, H.Y.; Lee, H.J.; Chang, Y.J.; Pichavant, M.; Shore, S.A.; Fitzgerald, K.A.; Iwakura, Y.; Israel, E.; Bolger, K.; Faul, J.; et al. Interleukin-17-producing innate lymphoid cells and the NLRP3 inflammasome facilitate obesity-associated airway hyperreactivity. Nat. Med. 2014, 20, 54-61. [CrossRef]

58. Li, S.; Bostick, J.W.; Ye, J.; Qiu, J.; Zhang, B.; Urban, J.F., Jr.; Avram, D.; Zhou, L. Aryl Hydrocarbon Receptor Signaling Cell Intrinsically Inhibits Intestinal Group 2 Innate Lymphoid Cell Function. Immunity 2018, 49, 915-928.e5. [CrossRef]

59. Kiss, E.A.; Vonarbourg, C.; Kopfmann, S.; Hobeika, E.; Finke, D.; Esser, C.; Diefenbach, A. Natural aryl hydrocarbon receptor ligands control organogenesis of intestinal lymphoid follicles. Science 2011, 334, 1561-1565. [CrossRef] 
60. Lee, J.S.; Cella, M.; McDonald, K.G.; Garlanda, C.; Kennedy, G.D.; Nukaya, M.; Mantovani, A.; Kopan, R.; Bradfield, C.A.; Newberry, R.D.; et al. AHR drives the development of gut ILC22 cells and postnatal lymphoid tissues via pathways dependent on and independent of Notch. Nat. Immunol. 2011, 13, 144-151. [CrossRef]

61. Qiu, J.; Heller, J.J.; Guo, X.; Chen, Z.M.; Fish, K.; Fu, Y.X.; Zhou, L. The aryl hydrocarbon receptor regulates gut immunity through modulation of innate lymphoid cells. Immunity 2012, 36, 92-104. [CrossRef] [PubMed]

62. Stockinger, B.; Di Meglio, P.; Gialitakis, M.; Duarte, J.H. The aryl hydrocarbon receptor: Multitasking in the immune system. Annu. Rev. Immunol. 2014, 32, 403-432. [CrossRef] [PubMed]

63. Kimura, A.; Naka, T.; Nohara, K.; Fujii-Kuriyama, Y.; Kishimoto, T. Aryl hydrocarbon receptor regulates Stat1 activation and participates in the development of Th17 cells. Proc. Natl. Acad. Sci. USA 2008, 105, 9721-9726. [CrossRef] [PubMed]

64. Quintana, F.J.; Basso, A.S.; Iglesias, A.H.; Korn, T.; Farez, M.F.; Bettelli, E.; Caccamo, M.; Oukka, M.; Weiner, H.L. Control of T(reg) and T(H)17 cell differentiation by the aryl hydrocarbon receptor. Nature 2008, 453, 65-71. [CrossRef]

65. Veldhoen, M.; Hirota, K.; Westendorf, A.M.; Buer, J.; Dumoutier, L.; Renauld, J.C.; Stockinger, B. The aryl hydrocarbon receptor links TH17-cell-mediated autoimmunity to environmental toxins. Nature 2008, 453, 106-109. [CrossRef]

66. Ple, C.; Fan, Y.; Ait Yahia, S.; Vorng, H.; Everaere, L.; Chenivesse, C.; Balsamelli, J.; Azzaoui, I.; de Nadai, P.; Wallaert, B.; et al. Polycyclic aromatic hydrocarbons reciprocally regulate IL-22 and IL-17 cytokines in peripheral blood mononuclear cells from both healthy and asthmatic subjects. PLoS ONE 2015, 10, e0122372. [CrossRef]

67. Trifari, S.; Kaplan, C.D.; Tran, E.H.; Crellin, N.K.; Spits, H. Identification of a human helper T cell population that has abundant production of interleukin 22 and is distinct from $\mathrm{T}(\mathrm{H})-17, \mathrm{~T}(\mathrm{H}) 1$ and $\mathrm{T}(\mathrm{H}) 2$ cells. Nat. Immunol. 2009, 10, 864-871. [CrossRef]

68. Mascanfroni, I.D.; Takenaka, M.C.; Yeste, A.; Patel, B.; Wu, Y.; Kenison, J.E.; Siddiqui, S.; Basso, A.S.; Otterbein, L.E.; Pardoll, D.M.; et al. Metabolic control of type 1 regulatory T cell differentiation by AHR and HIF1-alpha. Nat. Med. 2015, 21, 638-646. [CrossRef]

69. Lee, Y.; Awasthi, A.; Yosef, N.; Quintana, F.J.; Xiao, S.; Peters, A.; Wu, C.; Kleinewietfeld, M.; Kunder, S.; Hafler, D.A.; et al. Induction and molecular signature of pathogenic TH17 cells. Nat. Immunol. 2012, 13, 991-999. [CrossRef]

70. Funatake, C.J.; Marshall, N.B.; Steppan, L.B.; Mourich, D.V.; Kerkvliet, N.I. Cutting edge: Activation of the aryl hydrocarbon receptor by 2,3,7,8-tetrachlorodibenzo-p-dioxin generates a population of CD4+ CD25+ cells with characteristics of regulatory T cells. J. Immunol. 2005, 175, 4184-4188. [CrossRef]

71. Gandhi, R.; Kumar, D.; Burns, E.J.; Nadeau, M.; Dake, B.; Laroni, A.; Kozoriz, D.; Weiner, H.L.; Quintana, F.J. Activation of the aryl hydrocarbon receptor induces human type 1 regulatory T cell-like and Foxp3(+) regulatory T cells. Nat. Immunol. 2010, 11, 846-853. [CrossRef] [PubMed]

72. Singh, N.P.; Singh, U.P.; Singh, B.; Price, R.L.; Nagarkatti, M.; Nagarkatti, P.S. Activation of aryl hydrocarbon receptor (AhR) leads to reciprocal epigenetic regulation of FoxP3 and IL-17 expression and amelioration of experimental colitis. PLoS ONE 2011, 6, e23522. [CrossRef] [PubMed]

73. Suarez-Alvarez, B.; Rodriguez, R.M.; Fraga, M.F.; Lopez-Larrea, C. DNA methylation: A promising landscape for immune system-related diseases. Trends Genet. 2012, 28, 506-514. [CrossRef] [PubMed]

74. Nadeau, K.; McDonald-Hyman, C.; Noth, E.M.; Pratt, B.; Hammond, S.K.; Balmes, J.; Tager, I. Ambient air pollution impairs regulatory T-cell function in asthma. J. Allergy Clin. Immunol. 2010, 126, 845-852.e810. [CrossRef] [PubMed]

75. Apetoh, L.; Quintana, F.J.; Pot, C.; Joller, N.; Xiao, S.; Kumar, D.; Burns, E.J.; Sherr, D.H.; Weiner, H.L.; Kuchroo, V.K. The aryl hydrocarbon receptor interacts with c-Maf to promote the differentiation of type 1 regulatory T cells induced by IL-27. Nat. Immunol. 2010, 11, 854-861. [CrossRef] [PubMed]

76. Tousa, S.; Semitekolou, M.; Morianos, I.; Banos, A.; Trochoutsou, A.I.; Brodie, T.M.; Poulos, N.; Samitas, K.; Kapasa, M.; Konstantopoulos, D.; et al. Activin-A co-opts IRF4 and AhR signaling to induce human regulatory T cells that restrain asthmatic responses. Proc. Natl. Acad. Sci. USA 2017, 114, E2891-E2900. [CrossRef]

77. Gagliani, N.; Amezcua Vesely, M.C.; Iseppon, A.; Brockmann, L.; Xu, H.; Palm, N.W.; de Zoete, M.R.; Licona-Limon, P.; Paiva, R.S.; Ching, T.; et al. Th17 cells transdifferentiate into regulatory T cells during resolution of inflammation. Nature 2015, 523, 221-225. [CrossRef] 
78. Wei, P.; Hu, G.H.; Kang, H.Y.; Yao, H.B.; Kou, W.; Liu, H.; Zhang, C.; Hong, S.L. An aryl hydrocarbon receptor ligand acts on dendritic cells and T cells to suppress the Th17 response in allergic rhinitis patients. Lab. Investig. 2014, 94, 528-535. [CrossRef]

79. Vaidyanathan, B.; Chaudhry, A.; Yewdell, W.T.; Angeletti, D.; Yen, W.F.; Wheatley, A.K.; Bradfield, C.A.; McDermott, A.B.; Yewdell, J.W.; Rudensky, A.Y.; et al. The aryl hydrocarbon receptor controls cell-fate decisions in B cells. J. Exp. Med. 2017, 214, 197-208. [CrossRef]

80. Piper, C.J.M.; Rosser, E.C.; Oleinika, K.; Nistala, K.; Krausgruber, T.; Rendeiro, A.F.; Banos, A.; Drozdov, I.; Villa, M.; Thomson, S.; et al. Aryl Hydrocarbon Receptor Contributes to the Transcriptional Program of IL-10-Producing Regulatory B Cells. Cell Rep. 2019, 29, 1878-1892.e7. [CrossRef]

81. Rosser, E.C.; Piper, C.J.M.; Matei, D.E.; Blair, P.A.; Rendeiro, A.F.; Orford, M.; Alber, D.G.; Krausgruber, T.; Catalan, D.; Klein, N.; et al. Microbiota-Derived Metabolites Suppress Arthritis by Amplifying Aryl-Hydrocarbon Receptor Activation in Regulatory B Cells. Cell Metab. 2020, 31, 837-851.e810. [CrossRef] [PubMed]

82. Heijink, I.H.; Kuchibhotla, V.N.S.; Roffel, M.P.; Maes, T.; Knight, D.A.; Sayers, I.; Nawijn, M.C. Epithelial cell dysfunction, a major driver of asthma development. Allergy 2020, 75, 1902-1917. [CrossRef] [PubMed]

83. Potaczek, D.P.; Miethe, S.; Schindler, V.; Alhamdan, F.; Garn, H. Role of airway epithelial cells in the development of different asthma phenotypes. Cell Signal. 2020, 69, 109523. [CrossRef] [PubMed]

84. Somineni, H.K.; Zhang, X.; Biagini Myers, J.M.; Kovacic, M.B.; Ulm, A.; Jurcak, N.; Ryan, P.H.; Khurana Hershey, G.K.; Ji, H. Ten-eleven translocation 1 (TET1) methylation is associated with childhood asthma and traffic-related air pollution. J. Allergy Clin. Immunol. 2016, 137, 797-805.e795. [CrossRef]

85. Burleson, J.D.; Siniard, D.; Yadagiri, V.K.; Chen, X.; Weirauch, M.T.; Ruff, B.P.; Brandt, E.B.; Hershey, G.K.K.; Ji, H. TET1 contributes to allergic airway inflammation and regulates interferon and aryl hydrocarbon receptor signaling pathways in bronchial epithelial cells. Sci. Rep. 2019, 9, 7361. [CrossRef]

86. Thordardottir, S.; Hangalapura, B.N.; Hutten, T.; Cossu, M.; Spanholtz, J.; Schaap, N.; Radstake, T.R.; van der Voort, R.; Dolstra, H. The aryl hydrocarbon receptor antagonist StemRegenin 1 promotes human plasmacytoid and myeloid dendritic cell development from CD34+ hematopoietic progenitor cells. Stem. Cells Dev. 2014, 23, 955-967. [CrossRef]

87. Ou-Yang, H.F.; Huang, Y.; Hu, X.B.; Wu, C.G. Suppression of allergic airway inflammation in a mouse model of asthma by exogenous mesenchymal stem cells. Exp. Biol. Med. 2011, 236, 1461-1467. [CrossRef]

88. Bernardo, M.E.; Fibbe, W.E. Mesenchymal stromal cells: Sensors and switchers of inflammation. Cell Stem. Cell 2013, 13, 392-402. [CrossRef]

89. Do, D.C.; Zhao, Y.; Gao, P. Cockroach allergen exposure and risk of asthma. Allergy 2016, 71, $463-474$. [CrossRef]

90. Gao, P.; Zhou, Y.; Xian, L.; Li, C.; Xu, T.; Plunkett, B.; Huang, S.K.; Wan, M.; Cao, X. Functional effects of TGF-beta1 on mesenchymal stem cell mobilization in cockroach allergen-induced asthma. J. Immunol. 2014, 192, 4560-4570. [CrossRef]

91. Zhang, G.; Li, X.; Cheng, Y.; Yu, H.; Gu, W.; Cui, Z.; Xie, J.-L. 2,3,7,8-Tetrachlorodibenzo-p-dioxin-induced aryl hydrocarbon receptor activation enhanced the suppressive function of mesenchymal stem cells against splenocyte proliferation. Vitr. Cell. Dev. Biol. Anim. 2019, 55, 633-640. [CrossRef] [PubMed]

92. Cui, Z.; Feng, Y.; Li, D.; Li, T.; Gao, P.; Xu, T. Activation of aryl hydrocarbon receptor (AhR) in mesenchymal stem cells modulates macrophage polarization in asthma. J. Immunotoxicol. 2020, 17, 21-30. [CrossRef] [PubMed]

93. Tripathi, P.; Deng, F.; Scruggs, A.M.; Chen, Y.; Huang, S.K. Variation in doses and duration of particulate matter exposure in bronchial epithelial cells results in upregulation of different genes associated with airway disorders. Toxicol. Vitr. 2018, 51, 95-105. [CrossRef]

94. Yang, Q.; Ge, M.Q.; Kokalari, B.; Redai, I.G.; Wang, X.; Kemeny, D.M.; Bhandoola, A.; Haczku, A. Group 2 innate lymphoid cells mediate ozone-induced airway inflammation and hyperresponsiveness in mice. J. Allergy Clin. Immunol. 2016, 137, 571-578. [CrossRef] [PubMed]

95. Cai, T.; Qiu, J.; Ji, Y.; Li, W.; Ding, Z.; Suo, C.; Chang, J.; Wang, J.; He, R.; Qian, Y.; et al. IL-17-producing $\mathrm{ST} 2(+)$ group 2 innate lymphoid cells play a pathogenic role in lung inflammation. J. Allergy Clin. Immunol. 2019, 143, 229-244.e229. [CrossRef]

96. Hiraiwa, K.; van Eeden, S.F. Contribution of lung macrophages to the inflammatory responses induced by exposure to air pollutants. Mediat. Inflamm. 2013, 2013, 1-10. [CrossRef] 
97. Al-Alwan, L.A.; Chang, Y.; Mogas, A.; Halayko, A.J.; Baglole, C.J.; Martin, J.G.; Rousseau, S.; Eidelman, D.H.; Hamid, Q. Differential roles of CXCL2 and CXCL3 and their receptors in regulating normal and asthmatic airway smooth muscle cell migration. J. Immunol. 2013, 191, 2731-2741. [CrossRef]

98. Podechard, N.; Lecureur, V.; Le Ferrec, E.; Guenon, I.; Sparfel, L.; Gilot, D.; Gordon, J.R.; Lagente, V.; Fardel, O. Interleukin-8 induction by the environmental contaminant benzo(a)pyrene is aryl hydrocarbon receptor-dependent and leads to lung inflammation. Toxicol. Lett. 2008, 177, 130-137. [CrossRef]

99. Van Voorhis, M.; Knopp, S.; Julliard, W.; Fechner, J.H.; Zhang, X.; Schauer, J.J.; Mezrich, J.D. Exposure to atmospheric particulate matter enhances Th17 polarization through the aryl hydrocarbon receptor. PLOS ONE 2013, 8, e82545. [CrossRef]

100. Buck, M.D.; O'Sullivan, D.; Pearce, E.L. T cell metabolism drives immunity. J. Exp. Med. 2015, 212, $1345-1360$. [CrossRef]

101. Zhu, J.; Cao, Y.; Li, K.; Wang, Z.; Zuo, P.; Xiong, W.; Xu, Y.; Xiong, S. Increased expression of aryl hydrocarbon receptor and interleukin 22 in patients with allergic asthma. Asian Pac. J. Allergy Immunol. 2011, 29, $266-272$. [PubMed]

102. Okey, A.B.; Franc, M.A.; Moffat, I.D.; Tijet, N.; Boutros, P.C.; Korkalainen, M.; Tuomisto, J.; Pohjanvirta, R. Toxicological implications of polymorphisms in receptors for xenobiotic chemicals: The case of the aryl hydrocarbon receptor. Toxicol. Appl. Pharmacol. 2005, 207, 43-51. [CrossRef] [PubMed]

103. Lee, Y.H.; Lin, C.H.; Hsu, P.C.; Sun, Y.Y.; Huang, Y.J.; Zhuo, J.H.; Wang, C.Y.; Gan, Y.L.; Hung, C.C.; Kuan, C.Y.; et al. Aryl hydrocarbon receptor mediates both proinflammatory and anti-inflammatory effects in lipopolysaccharide-activated microglia. Glia 2015, 63, 1138-1154. [CrossRef] [PubMed]

104. Hidaka, T.; Ogawa, E.; Kobayashi, E.H.; Suzuki, T.; Funayama, R.; Nagashima, T.; Fujimura, T.; Aiba, S.; Nakayama, K.; Okuyama, R.; et al. The aryl hydrocarbon receptor AhR links atopic dermatitis and air pollution via induction of the neurotrophic factor artemin. Nat. Immunol. 2017, 18, 64-73. [CrossRef] [PubMed]

Publisher's Note: MDPI stays neutral with regard to jurisdictional claims in published maps and institutional affiliations.

(C) 2020 by the authors. Licensee MDPI, Basel, Switzerland. This article is an open access article distributed under the terms and conditions of the Creative Commons Attribution (CC BY) license (http://creativecommons.org/licenses/by/4.0/). 